\title{
Development of automotive emissions testing equipment and test methods in response to legislative, technical and commercial requirements
}

\begin{abstract}
Legislation regarding the reduction of harmful exhaust emissions, greenhouse gases and fuel consumption is one of the strongest drivers of development in automobile design. Strict legislation requires changes to engine calibration and hardware, but also to test facilities and emissions analysis systems; indeed, emissions standards in the European Union (EU), USA and Japan determine not only maximum permissible emissions factors, but also emissions testing methods and laboratory design. This paper is a continuation of [1], and presents the most recent additions to BOSMAL's emissions testing laboratory - a recently-installed analyzer bench for modal raw exhaust measurement at both pre-and postcatalytic converter sampling locations, as well as EGR ratio calculation, are described in the context of its sophisticated emissions measurement facilities and the increasingly complex testing demands of vehicle and aftertreatment system manufacturers.
\end{abstract}

Key words: emissions testing, test laboratory, regulated emissions, cold start, alternative fuel

\section{Rozwój aparatury i metod badawczych emisji związków szkodliwych spalin samochodowych w aspekcie wymagań prawnych, technicznych i ekonomicznych}

\begin{abstract}
Zmiany w przepisach dotyczących obniżenia emisji związów szkodliwych spalin, gazów cieplarnianych, a także zmniejszenia zużycia paliwa są obecnie jednymi z najważniejszych czynników wpływających na kierunki rozwoju motoryzacji. Coraz bardziej wymagające normy emisji zmuszają do dokonania zmian nie tylko $w$ konstrukcji i regulacji silników spalinowych, ale także w wyposażeniu badawczym i aparaturze pomiarowej stosowanych w laboratoriach prowadzacych badania rozwojowe samochodów i silników. W Unii Europejskiej, USA i Japonii przepisami prawnymi objęte są nie tylko maksymalnie dopuszczalne poziomy emisji, ale także metody badań emisji zwiazków szkodliwych spalin i wyposażenie laboratorium pomiarowego. Artykut ten jest kontynuacja poprzedniej pracy [1] i prezentuje najnowsze modyfikacje $i$ uzupetnienia w wyposażeniu badawczo-pomiarowym w laboratorium badania emisji związów szkodliwych spalin i stosowanych metodach pomiarowych - przede wszystkim nowo zainstalowany zestaw analizatorów stużący do modalnych pomiarów spalin nierozcieńczonych przed i za reaktorem katalitycznym, a także do pomiaru stopnia recyrkulacji spalin EGR) - w kontekście coraz bardziej złożonych wymagań dotyczacych emisji związków szkodliwych z samochodów wyposażonych również w nowe rozwiązania układów katalitycznego oczyszczania spalin.
\end{abstract}

Słowa kluczowe: badania emisji spalin, laboratorium badawcze emisji spalin, limity emisji, zimny rozruch silnika, paliwa alternatywne

\section{Introduction}

\subsection{Legislation and political pressures as drivers of automotive emissions testing}

Concern regarding the impact of the transport sector on air quality and greenhouse gas emissions remains high, both to the public in general, and particularly to legislators. Road transport remains one of the largest single sources of $\mathrm{CO}_{2}$ emissions in the $\mathrm{EU}[2,3]$. Finite resources of liquid fossil fuels and the harmful emissions associated with the combustion of such fuels - together with international commercial competition - are the major factors driving automotive vehicular development. The main trends in engine and vehicle design are currently driven by the requirements of legislation concerning harmful exhaust emissions and reducing carbon dioxide $\left(\mathrm{CO}_{2}\right)$ emissions. Vehicular transport is one of the biggest sources of harmful emissions and major changes in engine and vehicle design have been observed in the past few

\section{Wprowadzenie}

1.1. Przepisy prawne i polityczne uwarunkowania jako czynniki wpływające na rozwój metod badań emisji z pojazdów samochodowych

Zainteresowanie związane $\mathrm{z}$ wpływem sektora transportu na jakość powietrza i emisję antropogeniczną gazów cieplarnianych stale wzrasta - zarówno w opinii publicznej, jak i w organach ustawodawczych. Transport drogowy pozostaje jednym $\mathrm{z}$ największych źródeł emisji $\mathrm{CO}_{2} \mathrm{w}$ Unii Europejskiej $[2,3]$. Ograniczone zasoby paliw płynnych i wydzielanie szkodliwych gazów związane ze spalaniem tych paliw, wraz ze wzrostem międzynarodowej konkurencji w sprzedaży samochodów, stanowią najważniejsze czynniki wpływające na kierunki rozwoju przemysłu samochodowego. Podstawowe trendy w konstrukcji silników i całych pojazdów są obecnie bardzo zależne od wymagań norm emisji substancji szkodliwych spalin, a także przepisów do- 
years in response to emissions reduction legislation (in the EU: the introduction of the Euro 5 standard's restrictions over the years 2009/2011, and the scheduled introduction of Euro 6 in 2014/2015). An additional factor is widespread pressure for the reduction of greenhouse gases, mostly by reduction of $\mathrm{CO}_{2}$ emissions, but increasingly with attention also paid to other greenhouse gases released as a result of incomplete combustion (such as $\mathrm{CH}_{4}$ ) and side reactions which can occur within aftertreatment systems (such as $\mathrm{N}_{2} \mathrm{O}$ and $\mathrm{NO}_{2}$ ).

Such external pressures drive research and development work on new low-emission vehicles, the use of alternative fuels, new types of engines and increasing the efficiency of engines currently produced. Thus, emissions testing to quantify emissions of harmful compounds, $\mathrm{CO}_{2}$, fuel consumption, as well as measurements of the efficacy of devices designed to combat such emissions - has never been more important for the industry and for the engineering and scientific communities as a whole. In addition to being a necessary requirement for the introduction of new models and conformity of production testing, such advanced research methods can provide fascinating and valuable insights into the formation of pollutants and the fluxes of heat and chemical species through a vehicle's powertrain.

Maximum emission factors in the Euro 5 standard represent a significant reduction in comparison to the Euro 4 standard (decreases range from 20 to 80 per cent). Some of these maximum permissible masses per kilometre will be reduced still further upon the entry into force of Euro 6 . The Euro 6 standard will require passenger cars and light commercial vehicles (LCV) to have combined emissions of $\mathrm{HC}, \mathrm{CO}, \mathrm{NO}_{\mathrm{x}}$ and $\mathrm{PM}$ of under 1 gram per kilometre (for $\mathrm{CI}$ engines), and $1.16 \mathrm{~g} / \mathrm{km}$ (for SI engines), which presents a design challenge both in terms of engines and aftertreatment systems, and emissions analysis systems and automotive testing facilities. The lower emission factors specified in recent and future legislation require high-sensitivity detection methods, to minimize the effect caused by measurement uncertainties. This general requirement for statistical significance and accuracy is likely to be echoed in the EPA's forthcoming ' 1065 ' light duty test procedure. In addition to progressively stricter emissions limits, efforts are underway to make testing procedures more representative of real-world conditions. One effect of efforts in this area has been the introduction of cold-start testing at low ambient temperatures in EU, EPA and CARB legislation. Type approval legislation requirements for testing at $-7^{\circ} \mathrm{C}[4]$ and $-6.7^{\circ} \mathrm{C}[5,6]$ necessitate facilities for simulation of such conditions on demand, all year round.

Legislative testing requirements represent only the tip of the iceberg - reduced emissions limits necessitate research and development work in order to meet these standards. Knowledge of forthcoming emissions standards is imperative for the laboratory design process; in addition, fuel specifications and fuel quality standards, (together with megatrends such as engine downsizing and the use of alternative fuels) should be monitored in order to prepare test facilities which fully meet the needs of the industry $[2,3]$. tyczących redukcji emisji dwutlenku węgla $\left(\mathrm{CO}_{2}\right)$. Transport samochodowy jest jednym z największych źródeł szkodliwej emisji spalin i w ciągu ostatnich kilku lat zaobserwowano zmiany w konstrukcji silników spalinowych, będące odpowiedzią na prawne wymagania redukcji emisji (w Unii Europejskiej wprowadzenie normy Euro 5 w latach 2009/2011 i zapowiadana na lata 2014/2015 norma Euro 6). Dodatkowym czynnikiem wpływającym na zmiany konstrukcyjne pojazdów jest wzrost nacisku na redukcję gazów cieplarnianych, przede wszystkim przez obniżenie emisji $\mathrm{CO}_{2}$, ale także przez zwrócenie uwagi na inne gazy cieplarniane wytwarzane jako efekt niecałkowitego spalania (takie, jak $\mathrm{CH}_{4}$ ), a także będące wynikiem reakcji ubocznych występujących w systemie oczyszczania spalin (jak $\mathrm{N}_{2} \mathrm{O}$ i $\mathrm{NO}_{2}$ ).

Powyższe czynniki ukierunkowują badania i działania rozwojowe na pracę nad nowymi pojazdami o niskiej emisji, stosowanie paliw alternatywnych, wprowadzanie nowych, bardziej ekologicznych typów silników, a także zwiększanie sprawności silników już istniejących. Wynika z tego, że jeszcze nigdy testy emisji, w których wykonywany jest pomiar wagowy i zliczanie cząstek stałych, pomiar ilości wytworzonego $\mathrm{CO}_{2}$, zużycia paliwa, a także badań sprawności podzespołów ograniczających emisję, nie były tak istotne z punktu widzenia przemysłu i nauki. Zaawansowane metody badań emisji mogą dostarczać cennych wniosków dotyczących formowania się i przemieszczania zanieczyszczeń pochodzących od spalin silnikowych i strumieni ciepła przez jednostkę napędową pojazdu.

Maksymalne limity emisji zawarte w normie Euro 5 są znacznie niższe w stosunku do poprzedniej normy Euro 4 (redukcja od 20 do 80 \%). Część z tych limitów (dozwolonej masy cząstek spalin na kilometr) będzie ponownie obniżona wraz z wprowadzeniem normy Euro 6. Norma ta będzie wymagała od samochodów osobowych i lekkich pojazdów użytkowych, aby łączna emisja $\mathrm{HC}, \mathrm{CO}, \mathrm{NO}_{x}$ i cząstek stałych była poniżej 1 grama na kilometr dla pojazdów z silnikami ZS i 1,16 gram na kilometr dla samochodów z silnikami ZI, co stanowi duże wyzwanie dla konstrukcji silników, systemów oczyszczania spalin, a także dla metod i aparatury pomiarowej. Obniżanie limitów określone w aktualnych i przyszłych normach wymaga stosowania metod wykrywania związków szkodliwych cechujących się dużą dokładnością pomiaru, aby zminimalizować niepewności pomiaru. Główne wymaganie dotyczące znaczenia statystycznej analizy wyników i dokładności pomiarów będzie przedstawione przez Agencję Ochrony Środowiska USA w mającej się wkrótce ukazać procedurze ' 1065 ' dla lekkich pojazdów samochodowych. W związku z coraz surowszymi normami emisji, większą wagę przywiązuje się także do tego, by testy badawcze prowadzone były w warunkach jak najbardziej zbliżonych do naturalnych. Efektem takiego podejścia stało się wprowadzanie metodyki badawczej dla samochodu przy rozruchu zimnego silnika w niskich temperaturach otoczenia w Unii Europejskiej, EPA i CARB. Wprowadzenie wymagań dla badań w temperaturze otoczenia $-7{ }^{\circ} \mathrm{C}[4] \mathrm{i}-6,7^{\circ} \mathrm{C}[5,6]$ zmuszają laboratoria badawcze do dostosowania się do tych warunków i posiadania możliwości prowadzenia takich badań przez cały rok. 
This paper presents an in-depth analysis of various facets and implications of the aforementioned themes, using the ongoing development of BOSMAL's exhaust emissions laboratory [1] as a concrete example of the trends and processes which commonly occur in the field of automotive emissions testing.

\subsection{Cold start testing as a driver of automotive emissions testing}

Cold start emissions behaviour represents perhaps the greatest single issue for emissions control regarding passenger cars, and a key theme for the development of affective aftertreatment systems. Before an engine of any type can perform useful work, it must be started. In the case of passenger cars, each journey (or segment of a journey) necessitates a start-up event. The first phase of the NEDC test (the UDC) essentially consists of a cold start and a period of engine warm-up (Fig. 1). These start-up events are significant in terms of emissions and fuel consumption, with a strong dependency on the temperature of the engine. Cold start can be defined as when an engine is started with the temperatures of the oil, coolant and all elements of the engine $(\mathrm{T})$ at the ambient temperature $\left(\mathrm{T}_{\mathrm{a}}\right)$ [cold start (7)]. During hot start, the temperature of all these elements will be very close to those observed during fully warmed-up operation $\left(\mathrm{T}_{\mathrm{w}}\right)$. The term 'cool start' can be used to refer to intermediate temperatures (i.e. $\mathrm{T}_{\mathrm{a}}<\mathrm{T}<\mathrm{T}_{\mathrm{w}}$ ). One to two cold starts are experienced by each passenger car on most days; around $69 \%$ of all journeys begin with a cold or cool start [7]. Cool and cold starts represent a significant challenge in terms of forming combustible mixtures while maintaining exhaust emissions and fuel consumption at reasonable levels, and this problem becomes progressively worse with reducing ambient temperatures. Compression ignition (CI) engines are widely recognised as exhibiting lower excess emissions associated with cold start at low ambient temperatures than spark ignition (SI) engines [7], and have not (yet) been targeted in European Union (EU) legislation aimed at limiting excess emission during these events. However, CI engines do exhibit deteriorations in emissions and fuel consumption during cold start. Recent publications of note have examined this phenomenon [7 - 9], and future legislation may yet require a low ambient temperature cold start test for passenger cars with CI engines.

Currently, European Union type-approval (TA) requirements set limits of emissions of hydrocarbons (HC) and carbon monoxide (CO) for testing at $-7^{\circ} \mathrm{C}$, for SI vehicles only. (An additional
Coraz ostrzejsze wymagania ustawowe dotyczące testów emisji związków szkodliwych spalin są sporym wyzwaniem dla laboratoriów badawczych prowadzących pomiary w tym zakresie - obniżone limity emisji wymuszają prowadzenie prac rozwojowych, które pozwolą na spełnianie tych wymagań. Wiedza o planowanych i wprowadzanych normach w dziedzinie emisji spalin jest kluczowa dla procesu projektowania laboratoriów badawczych. Dodatkowymi czynnikami są wprowadzane nowe specyfikacje paliw silnikowych i ich normy jakości (razem z trendami w konstrukcji silników spalinowych, jak downsizing silników i stosowanie paliw alternatywnych). Wszystkie te tendencje muszą być stale monitorowane celem możliwie szybkiego przygotowywania laboratoriów badawczych spełniających wymogi ustawodawców i przemysłu [2, 3].

$\mathrm{W}$ artykule tym zaprezentowano dogłębną analizę różnych aspektów i konsekwencji ostatnio wprowadzanych zmian w przepisach i metodykach badawczych emisji związków szkodliwych spalin z podjazdów samochodowych na przykładzie modernizacji przeprowadzonych w laboratorium badania emisji Instytutu BOSMAL [1], jako konkretnego przykładu wdrażania tych tendencji i procesów, które powszechnie występują w dziedzinie badania emisji w motoryzacji.

\subsection{Testy emisji po rozruchu zimnego silnika jako kierunek badań samochodów}

Emisja związków szkodliwych podczas zimnego rozruchu silnika jest najważniejszym problemem związanym z kontrolą emisji spalin w samochodach osobowych, który musi być rozwiązany przez producentów silników, a także stanowi klucz do rozwoju systemów katalitycznego oczyszczania spalin. W odniesieniu do samochodów osobowych

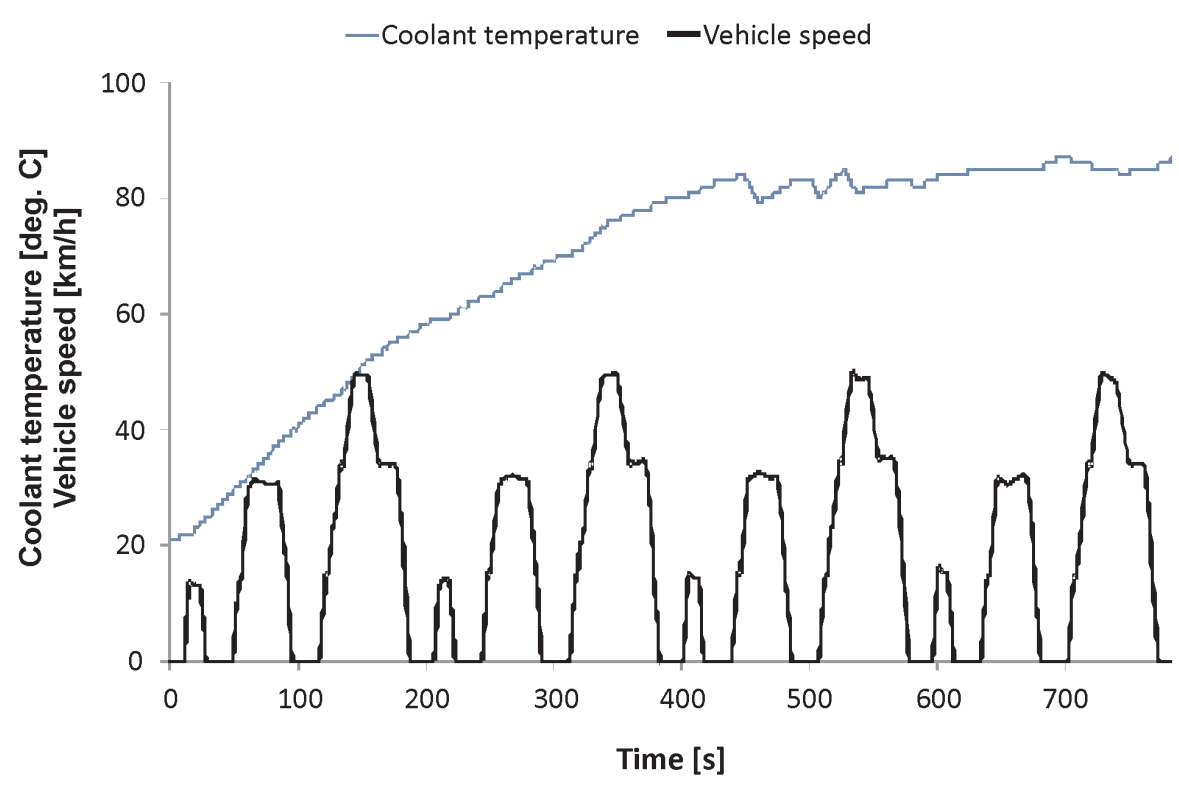

Fig. 1. Engine coolant temperature and vehicle speed for a vehicle with a small displacement SI engine tested at $24{ }^{\circ} \mathrm{C}$ over the first phase of the NEDC (the UDC; also used for Type VI testing at $-7{ }^{\circ} \mathrm{C}$ )

Rys. 1. Temperatura płynu chłodzacego i prędkość jazdy pojazdu z silnikiem o zapłonie iskrowym badanego w temp. $24^{\circ} \mathrm{C}$ podczas pierwszej fazy testu NEDC (faza UDC; wykorzystywana także podczas próby typu VI w temperaturze $-7^{\circ} \mathrm{C}$ ) 
requirement is now in place for type-approval testing of $\mathrm{CI}$ vehicles, which requires that the $\mathrm{NO}_{x}$ aftertreatment device reaches "a sufficiently high temperature for efficient operation" within 400 seconds following cold start at $-7^{\circ} \mathrm{C}$.) Federal US legislation requires a $\mathrm{CO}$ test at $20^{\circ} \mathrm{F}\left(-6.7^{\circ} \mathrm{C}\right)$. In 2004 the state of California set limits for $\mathrm{HC}, \mathrm{CO}$ and $\mathrm{NO}_{x}$ for all SI vehicles, with testing performed at $10{ }^{\circ} \mathrm{C}$. Since 1996, Californian legislation has also required a CO test for SI vehicles at $10^{\circ} \mathrm{C}$, with an upper limit of 10 grams/ mile. In addition to these legal testing requirements for SI vehicles, performing tests at a various ambient temperatures is of interest in multiple areas, such as: fuel research, catalyst research, powertrain development and research into regulated and unregulated emissions and 'real-world' emissions behaviours. Cold start testing has been identified as an activity of prime importance for manufacturers of vehicles with SI engines [10]. While the introduction of progressively stricter emissions standards and a cold start test at $-7^{\circ} \mathrm{C}$ have themselves had a great impact on the testing requirements of manufacturers of engine, vehicle and aftertreatment systems, measures to control emissions and fuel consumption during cold start have increased the number of system parameters, thereby causing a further increase in testing requirements [10]. Given the complexity of these systems, and the low emissions limits, the ability to collect data on engine out emissions, catalyst efficiency, catalyst temperature, etc, in addition to 'traditional' bag-sampled tailpipe emissions is a distinct advantage. Forearmed with this knowledge, BOSMAL commissioned a test facility capable of creating a wide range of ambient temperatures [1], in order to fulfil the needs of its customers, as well as its own scientific investigations. Additionally, the laboratory is now equipped with analysers for continuous and modal analysis of undiluted exhaust gas emissions at sampling locations both upstream and downstream of any aftertreatment device(s), thereby enabling greater insight into cold start emissions from a range of vehicles, fuel types, control strategies, etc.

\section{Characteristics of the upgraded laboratory}

\subsection{General description and capabilities}

The laboratory is an advanced, climate-controlled facility for performing emissions, fuel consumption and performance tests over a range of driving cycles and a broad range of ambient conditions. Emissions testing is carried out with the aid of sampling bags, raw and diluted modal analysis and a dilution tunnel (for use with CI and SI vehicles). These facilities permit the execution of a wide range of emissions tests, including:

- CVS bag diluted and raw tailpipe emissions testing to international standards $[4,11]$

- modal analysis of diluted and raw tailpipe gases

- modal analysis of raw exhaust sampled from two locations (nominally pre cat \& post cat, but the sampling locations are flexible)

- measurement and archival of temperatures from up to eight thermocouples mounted at different locations on the vehicle and on the exhaust line każda podróż (lub fragment podróży) wymaga operacji uruchomienia silnika samochodu. Pierwsza faza testu NEDC (UDC) składa się z rozruchu zimnego silnika i okresu, w którym silnik się nagrzewa (rys. 1). Rozruch silnika ma szczególne znaczenie $\mathrm{w}$ aspekcie emisji i zużycia paliwa, przy ścisłym związku z temperaturą silnika, przy której silnik jest uruchamiany. O ,zimnym rozruchu” mówi się wtedy, gdy silnik uruchamiany jest z temperaturą oleju, płynu chłodzącego i elementów silnika (T) w temperaturze otoczenia $\left(\mathrm{T}_{\mathrm{a}}\right)$ [7]. Podczas ,gorącego rozruchu” temperatura wszystkich elementów silnika, oleju i płynu chłodzącego jest bliska temperaturze panującej podczas pracy w pełni rozgrzanego silnika $\left(\mathrm{T}_{\mathrm{w}}\right)$. Termin ,chłodnego rozruchu” oznacza $\mathrm{z}$ kolei rozruch $\mathrm{w}$ temperaturach pośrednich $\left(\mathrm{T}_{\mathrm{a}}<\mathrm{T}<\mathrm{T}_{\mathrm{w}}\right)$. Najczęściej każdy użytkownik samochodu wykonuje jeden lub dwa zimne rozruchy dziennie - ok. $69 \%$ wszystkich podróży zaczyna się od uruchomienia zimnego silnika [7]. Rozruchy zimnego i nienagrzanego silnika stanowią poważne problemy w kontekście formowania mieszanki palnej, przy jednoczesnym utrzymywaniu emisji i zużycia paliwa na rozsądnym poziomie, a znaczenie tego problemu wzrasta wraz ze spadkiem temperatury otoczenia, w którym silnik jest uruchamiany i samochód będzie wykonywał jazdę.

Ponieważ silniki o zapłonie samoczynnym cechują się mniejszą emisją związaną z zimnym rozruchem w niskich temperaturach otoczenia niż silniki o zapłonie iskrowym [7], nie zostały więc jeszcze ustalone w Unii Europejskiej normy dotyczące emisji tych silników dla niskich temperatur, trwają jednak prace w tym zakresie. Problemem, który występuje podczas rozruchu i nagrzewania silników z zapłonem samoczynnym jest natomiast zużycie paliwa. W ostatnio publikowanych pracach badano to zjawisko [7 - 9] i przyszłe normy dotyczące rozruchu w niskich temperaturach otoczenia dla samochodów z silnikami o zapłonie samoczynnym wydają się nieuniknione.

Aktualne przepisy homologacyjne samochodów osobowych (TA) Unii Europejskiej zawierają również limity emisji węglowodorów i tlenków węgla w testach UDC przy temperaturze prowadzenia badań $-7^{\circ} \mathrm{C}$ tylko dla pojazdów z silnikami o zapłonie iskrowym. Obecnie dodatkowe wymaganie homologacyjne odniesiono do silników o zapłonie samoczynnym. Polega ono na osiągnięciu przez układy katalitycznego oczyszczania spalin z tlenków azotu temperatury umożliwiającej wydajną pracę w ciągu 400 sekund od zimnego rozruchu. Federalne przepisy amerykańskie wymagają testów na określenie emisji tlenku węgla przy $20^{\circ} \mathrm{F}\left(-6,7{ }^{\circ} \mathrm{C}\right)$. W roku $2004 \mathrm{w}$ stanie Kalifornia ustanowiono limity dla emisji $\mathrm{HC}, \mathrm{CO}$ i $\mathrm{NO}_{\mathrm{x}}$ dla wszystkich silników o zapłonie iskrowym przy temperaturze prowadzenia badań $\left(10^{\circ} \mathrm{C}\right)$. Od roku 1996 kalifornijskie normy wymagały, aby testy emisji CO przy $10{ }^{\circ} \mathrm{C}$ dawały rezultat poniżej 10 gramów na milę. Oprócz prawnych wymagań dotyczących badań samochodów z silnikami ZI, wykonywanie testów w różnych temperaturach otoczenia jest przedmiotem zainteresowania wielu dziedzin, takich jak: rozwój paliw, reaktorów katalitycznych, jednostek napędowych, a także badań emisji związków normowanych i nie- 
- measurement of the air-fuel ratio and calculation of $\lambda$ and the EGR percentage

- catalytic converter efficiency testing (and determination of light-off time) for elimination of $\mathrm{HC}, \mathrm{CH}_{4}, \mathrm{NMHC}$, $\mathrm{CO}, \mathrm{NO}, \mathrm{NO}_{2}$ and $\mathrm{NO}_{x}$

- $\mathrm{CO}_{2}$ emissions and fuel consumption measurement according to EU standards $[12,13]$

- opacity measurements according to EU standards [11, 12]

- gravimetric and numerical quantification of particulate matter emission according to $[4,13]$

- measurement of unregulated compounds such as $\mathrm{N}_{2} \mathrm{O}$, $\mathrm{NH}_{3}$ using an additional analyser (AVL AMAi60)

A schematic diagram of the upgraded laboratory is presented in Fig. 2.

\subsection{Climatic chamber}

The base of the laboratory is a climatic chamber within which emissions, fuel consumption and performance measurements are performed at temperatures ranging from $-35{ }^{\circ} \mathrm{C}$ to $+60{ }^{\circ} \mathrm{C}$ (Fig. 3). Such a temperature range far exceeds current legislative requirements; the $95^{\circ} \mathrm{C}$ temperature range capability is a response to the current and future requirements of engine and vehicle development projects, cold startability at low temperatures, etc, and oil, fuel and catalyst manufacturers' testing demands. The chamber is equipped with temperature and humidity control systems, which facilitate the maintenance of the desired temperature and humidity levels. During operation of the chamber, (including during the execution of emission and vehicle performance tests), the chamber permits: normowanych oraz rzeczywistych emisji samochodowych. Rozruch zimnego silnika został zidentyfikowany jako zdarzenie wysokiej wagi dla producentów silników o zapłonie iskrowym [10]. Przy okazji wdrażania coraz surowszych standardów emisji spalin, które miały ogromny wpływ na producentów silników spalinowych, konstrukcję systemów recyrkulacji i katalitycznego oczyszczania spalin, okazało się, że podczas zimnych rozruchów należy kontrolować o wiele więcej parametrów jednocześnie niż podczas innych stanów pracy silnika, co wzmaga konieczność zwiększenia wymagań badawczych.

Biorąc pod uwagę złożoność tych systemów i niskie limity emisji, możliwość rejestrowania danych emisji silnika, sprawności i temperatury reaktora katalitycznego itp. jest bardzo istotną korzyścią, oprócz tradycyjnego pomiaru opartego na analizie z worków. W laboratorium emisji w BOSMAL istnieje możliwość regulacji dowolnej temperatury otoczenia, przy której wykonuje się badania emisji związków szkodliwych [1], przede wszystkim aby zaspokoić potrzeby klientów, ale także by poszerzyć własną wiedzę na temat rzeczywistej emisji samochodowej. Obecnie laboratorium emisji wyposażone jest w zestawy analizatorów do prowadzenia ciągłej i modalnej analizy nierozcieńczonych i rozcieńczonych spalin w dowolnym miejscu próbkowania przed i za każdym układem oczyszczania spalin, co umożliwia dokładniejszą analizę emisji podczas zimnych rozruchów dla pojazdów z silnikami różnych typów napędzanymi różnymi paliwami.

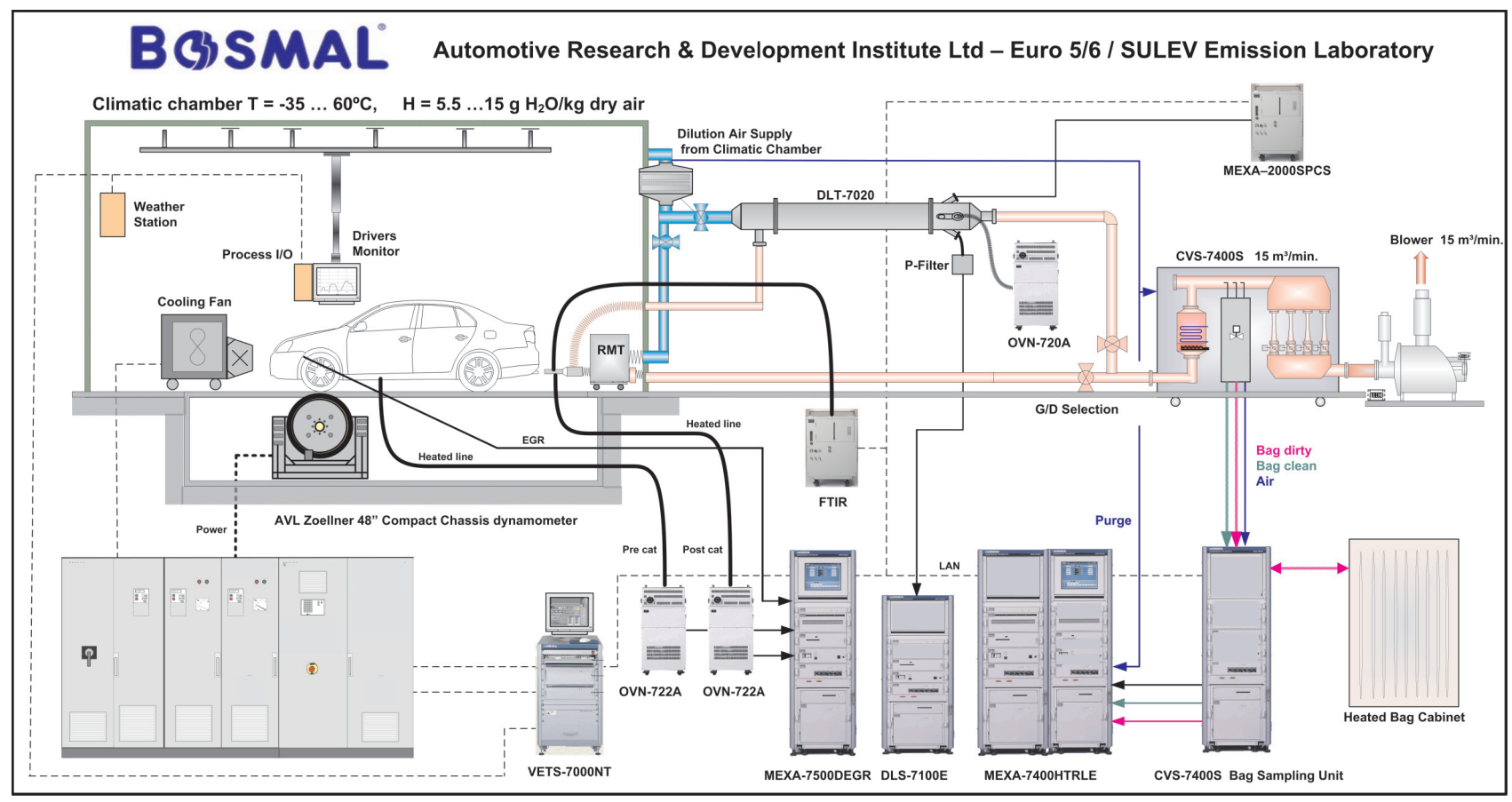

Fig. 2. Schematic diagram of the upgraded laboratory, showing the climatic chamber, chassis dynamometer, dilution tunnel, emissions sampling bags and all analysers, including the recently-added modal raw exhaust analyzer lines

Rys. 2. Schemat zmodyfikowanego laboratorium emisji z komora klimatyczna, hamownia podwoziowa, tunelem rozcieńczajacym spaliny powietrzem, workami na próbki spalin, analizatorami spalin wraz z nowo dodanym zestawem analizatorów do analizy modalnej spalin nierozcieńczonych 
- temperature control over the range $-35^{\circ} \mathrm{C}$ to $+60^{\circ} \mathrm{C}$

- control accuracy (temperature tolerance): $\pm 1.0^{\circ} \mathrm{C}$ (under static conditions, with zero heat load); $\pm 1.2{ }^{\circ} \mathrm{C}$ (during emissions tests); $\pm 2{ }^{\circ} \mathrm{C}$ (during performance tests)

- control over the humidity value during emissions tests: from 5.5 to 15.0 grams of water per kilogram of dry air at temperatures ranging from +20 to $+35{ }^{\circ} \mathrm{C}$

- variation in humidity level: $\leq 5 \%$

- temperature gradient (with the chamber empty): $0.5{ }^{\circ} \mathrm{C}$ per minute during warm-up and cooldown phases.

The chamber control software permits the execution of user-defined automated programmes, so that stabilisation of the temperature in the chamber can be achieved well before any testing begins (Fig. 4). The chamber roof features standard lamps to provide even illumination throughout the chamber, but may be upgraded to include high-power solar lamps in the future, as required for the EPA's supplemental air conditioning test cycle ('SC03'), performed at a temperature of $+35^{\circ} \mathrm{C}$ [5].

The laboratory's chassis dynamometer (AVL Zoellner 48" compact) is mounted in the chamber floor (see Fig. 3). Fully integrated in the laboratory management system (HORIBA VETS), it permits the execution of a wide range of driving cycles (NEDC, UDC, FTP-75, US06, SC03, HWFET, etc; new cycles can be rapidly implemented through additions to the software - a preliminary version of the forthcoming WLTC cycle has already been added). This device, and its computer control system have been described more fully elsewhere [1].

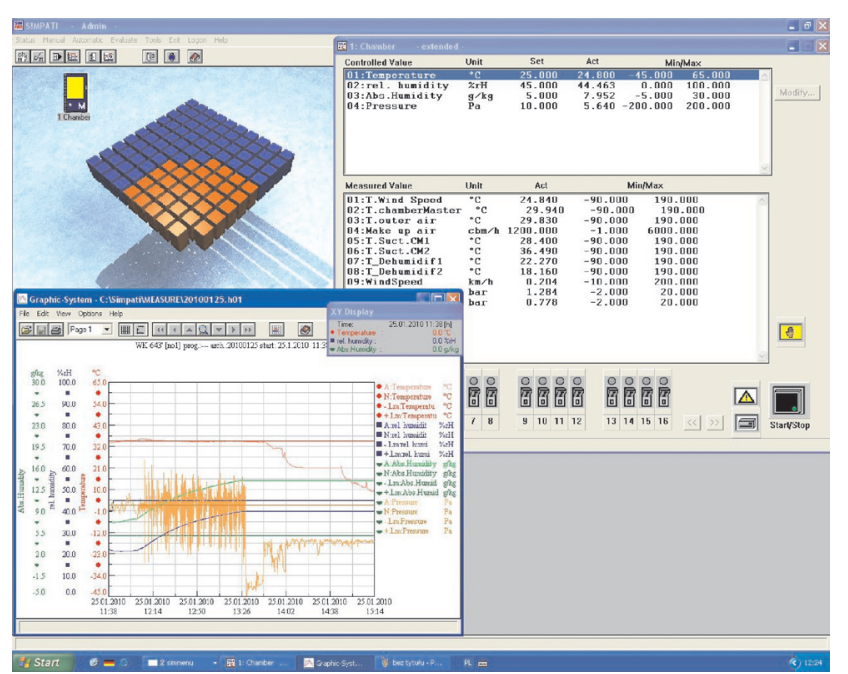

Fig. 4. Simpati climatic chamber control software

Rys. 4. System kontroli komory klimatycznej Simpati

\subsection{Upgraded emissions testing system}

The laboratory features an emissions analysis consisting of a CVS-CFV sampling system together with a dilution tunnel, a particulate sampling system, a particle number counting system, a set of exhaust analysers (Fig. 6) for

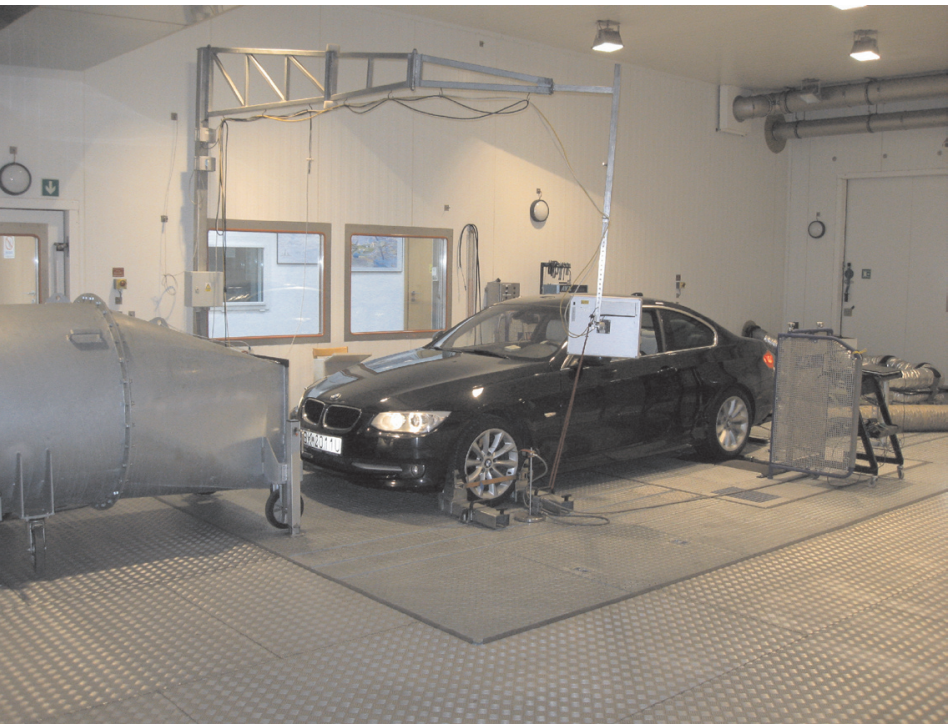

ig. 3. Internal view of the climatic chamber, showing the windspeed fan and driver's aid mounted in front of a vehicle positioned on the chassis dynamometer

Rys. 3. Komora klimatyczna z wentylatorem chłodzacym samochód i monitorem z przebiegiem cyklu jezdnego, zamontowanym przed samochodem stojacym na hamowni podwoziowej

\section{Opis wprowadzonych modernizacji w laboratorium badania emisji spalin}

\subsection{Możliwości badawcze laboratorium}

Laboratorium emisji zostało zbudowane w klimatyzowanym pomieszczeniu do prowadzenia testów jezdnych samochodu, w którym zamontowana jest hamownia podwoziowa i które służy do prowadzenia testów emisji związków szkodliwych w spalinach, zużycia paliwa i osiągów samochodu podczas różnych cykli jezdnych, które mogą być wykonywane się w szerokim zakresie temperatur otoczenia. Testy emisji typu homologacyjnego wykonuje się z wykorzystaniem specjalnych worków z tworzywa sztucznego (tedlar) do pobierania próbek spalin rozcieńczonych powietrzem $\mathrm{z}$ otoczenia, a także tunelu rozcieńczającego (dla silników zarówno z zapłonem iskrowym, jak i z zapłonem samoczynnym). Laboratorium jest przystosowane do prowadzenia bardzo różnorodnych typów badan:

- badania próbki spalin rozcieńczonych powietrzem z wykorzystaniem układu CVS oraz badania spalin nierozcieńczonych zgodnie z międzynarodowymi przepisami $[4,11]$

- analiza modalna spalin rozcieńczonych i nierozcieńczonych

- pomiary spalin nierozcieńczonych w dowolnym punkcie w układzie wylotowym silnika (głównie przed i za reaktorem katalitycznym)

- pomiary i archiwizacja temperatur z 8 możliwych do umieszczenia na układzie wylotowym termopar

- pomiary stosunku powietrza i paliwa dostarczanych do silnika oraz obliczanie współczynnika nadmiaru powietrza $\lambda$ i stopnia recyrkulacji spalin EGR

- pomiary skuteczności konwersji reaktora katalitycznego oraz określanie czasu light off w celu utleniania i redukcji związków szkodliwych ( $\mathrm{HC}, \mathrm{CH}_{4}, \mathrm{NMHC}, \mathrm{CO}, \mathrm{NO}, \mathrm{NO}_{2}$ i $\mathrm{NO}_{\mathrm{x}}$ ) 
Table 1. Component detection ranges of the exhaust gas analysis system

Tabela 1. Zakresy pomiarowe zastosowanych analizatorów spalin w systemie pomiarowym emisji związków szkodliwych

\begin{tabular}{|c|c|c|c|c|c|c|c|c|c|c|c|c|c|}
\hline \multicolumn{14}{|c|}{ MEXA 7400 HTRLE + MEXA 7500 DEGR Emissions Analysis System } \\
\hline \multicolumn{2}{|l|}{ Line } & \multicolumn{2}{|c|}{ Low Emission } & \multicolumn{2}{|c|}{ Diluted } & \multicolumn{2}{|c|}{ CO2Tracer } & \multicolumn{2}{|c|}{ PreCat } & \multicolumn{2}{|c|}{ PostCat } & \multicolumn{2}{|c|}{ EGR } \\
\hline \multirow{2}{*}{\multicolumn{2}{|c|}{$\begin{array}{l}\text { Component } \\
\text { (detection principle) }\end{array}$}} & \multicolumn{2}{|c|}{ Range } & \multicolumn{2}{|c|}{ Range } & \multicolumn{2}{|c|}{ Range } & \multicolumn{2}{|c|}{ Range } & \multicolumn{2}{|c|}{ Range } & \multicolumn{2}{|c|}{ Range } \\
\hline & & lowest & highest & lowest & highest & lowest & highest & lowest & highest & lowest & highest & lowest & highest \\
\hline \multirow{2}{*}{$\begin{array}{l}\mathrm{CO} \\
\text { (NDIR) }\end{array}$} & Low $[\mathrm{ppm}]$ & \multirow{2}{*}{$0-10$} & \multirow{2}{*}{$0-500$} & $0-50$ & $0-2500$ & \multirow{2}{*}{ - } & \multirow{2}{*}{-} & $0-50$ & $0-5000$ & $0-50$ & $0-5000$ & \multirow{2}{*}{-} & \multirow{2}{*}{ - } \\
\hline & High [\%] & & & $0-0.5$ & $0-12$ & & & $0-0.5$ & $0-12$ & $0-0.5$ & $0-12$ & & \\
\hline \multicolumn{2}{|c|}{$\mathrm{CO}_{2}$ (NDIR) [\%] } & $0-0.5$ & $0-20$ & $0-0.5$ & $0-20$ & $0-0.5$ & $0-20$ & $0-0.5$ & $0-20$ & $0-0.5$ & $0-20$ & $0-0.5$ & $0-20$ \\
\hline \multicolumn{2}{|c|}{$\mathrm{O}_{2}$ (MPA) [\%] } & - & - & - & - & - & - & $0-1$ & $0-25$ & - & - & - & - \\
\hline \multirow{2}{*}{$\begin{array}{l}\mathrm{NO}_{\mathrm{x}} \\
(\mathrm{CLD})\end{array}$} & Low [ppm] & $0-1$ & $0-50$ & $0-10$ & $0-500$ & \multirow{2}{*}{-} & \multirow{2}{*}{-} & \multirow{2}{*}{$0-10$} & \multirow{2}{*}{$0-10000$} & \multirow{2}{*}{$0-10$} & \multirow{2}{*}{$0-10000$} & \multirow{2}{*}{ - } & \multirow{2}{*}{ - } \\
\hline & High [ppm] & $0-100$ & $0-1000$ & $0-1000$ & $0-10000$ & & & & & & & & \\
\hline $\mathrm{NO}(\mathrm{CLI}$ & [ppm] & - & - & - & - & - & - & $0-10$ & $0-10000$ & $0-10$ & $0-10000$ & - & - \\
\hline & Low [ppmC1] & & & $0-10$ & $0-500$ & & & & & & & & \\
\hline $\begin{array}{l}\text { Gasoline } \\
\text { (FID) }\end{array}$ & High [ppmC1] & $0-1$ & $0-50$ & $0-1000$ & $0-50000$ & - & - & - & - & - & - & - & - \\
\hline THC & Low [ppmC1] & & & $0-10$ & $0-500$ & & & & & & & & \\
\hline $\begin{array}{l}\text { Diesel } \\
\text { (HFID) }\end{array}$ & High [ppmC1] & - & - & $0-1000$ & $0-50000$ & - & - & - & - & - & - & - & - \\
\hline $\mathrm{CH} 4$ (GC & FID) [ppm C1] & $0-1$ & $0-500$ & - & - & - & - & - & - & - & - & - & - \\
\hline $\mathrm{THC}(\mathrm{HF}$ & D) [ppmC1] & - & - & - & - & - & - & $0-10$ & $0-50000$ & $0-10$ & $0-50000$ & - & - \\
\hline $\mathrm{THC} / \mathrm{Cl}$ & (HFID) [ppmC1] & - & - & - & - & - & - & $0-10$ & $0-50000$ & $0-10$ & $0-50000$ & - & - \\
\hline
\end{tabular}

simultaneous measurement of carbon monoxide, carbon dioxide, total hydrocarbons, non-methane hydrocarbons, methane and oxides of nitrogen $\left(\mathrm{NO}+\mathrm{NO}_{2}\right)$, (Fig. 5, Tab. 1) and another exhaust analyser system (for measurement of raw $\mathrm{HC}, \mathrm{CH}_{4}, \mathrm{NMHC}, \mathrm{CO}, \mathrm{CO}_{2}, \mathrm{O}_{2}, \mathrm{NO}, \mathrm{NO}_{2}, \mathrm{NO}_{\mathrm{x}}$ and the EGR percentage) all controlled by the laboratory management system VETS (Vehicle emissions testing system). Figure 6 and 7 show an overview of the upgraded system. Sample bags for the sampling of ambient and exhaust air are housed in a heated, insulated unit maintained at $35^{\circ} \mathrm{C}$ to prevent condensation (Fig. 8). Analysers for measuring raw emissions of $\mathrm{THC}, \mathrm{CH}_{4}$ and $\mathrm{NO}_{\mathrm{x}}$ are sited separately from the main analyser racks (Fig. 9).

Two independent sampling lines for exhaust gases were previously installed: a separate line for SI engines with a mixing tee; and a second for CI engines with a dilution tunnel [1]. In the recent upgrade, heated lines for the sampling of raw exhaust gases are installed in the chamber, of sufficient length to test all types of vehicles up to $3500 \mathrm{~kg}$, both front- and rear-wheel drive. One of the design criteria for the laboratory was the possibility of adding extra modules to fulfil additional analytic requirements. The laboratory has already been used in conjunction with a standalone $\mathrm{NH}_{3}$ analyser for the ammonia emissions analysis from CI and SI automobile engines (especially fuelled with CNG) [14], as well as an FTIR analyser (for quantification of a wide range of regulated and unregulated exhaust gas compounds) [15]. A particle size classifier could also be added to the dilution tunnel for research and development purposes which focus on Diesel and direct injection (DI) SI engines and their respective particulate traps.

VETS7000NT control software maintains the analysers and their various activities during testing and analysis of bag emissions, such as zeroing, spanning, etc (Fig. 10).
- pomiary emisji $\mathrm{CO}_{2}$ i zużycia paliwa zgodnie z przepisami $\mathrm{UE}[12,13]$

- pomiary nieprzeźroczystości spalin zgodnie z przepisami UE $[11,12]$

- masowy pomiar emisji cząstek stałych i określanie liczby emitowanych cząstek stałych według $[4,13]$

- pomiary związków nieobjętych limitami emisji w przepisach, takich jak $\mathrm{N}_{2} \mathrm{O}, \mathrm{NH}_{3}$ przy użyciu dodatkowego analizatora (AVL AMAi60).

Schemat zmodyfikowanego laboratorium jest przedstawiony na rys. 2 .

\subsection{Komora klimatyczna}

Komora klimatyczna stanowi podstawową część laboratorium. W szerokim zakresie temperatur (od $-35{ }^{\circ} \mathrm{C}$ do $+60{ }^{\circ} \mathrm{C}$, rys. 3) bada się w niej emisję związków szkodliwych spalin, zużycie paliwa i osiągi silnika i samochodu. Zakres ten wykracza poza obecne wymagania przepisów dotyczących emisji, ale jest bardzo przydatny w prowadzonych pracach rozwojowych nad nowymi i modernizowanymi pojazdami i ich silnikami. Szeroki zakres temperatur otoczenia, w których mogą być prowadzone badania $\left(95^{\circ} \mathrm{C}\right)$ jest odpowiedzą na obecne $\mathrm{i}$ przyszłe wymagania badawcze producentów silników, olejów smarujących, paliw i reaktorów katalitycznych. Komora pomiarowa wyposażona jest w systemy kontroli temperatury i wilgotności powietrza, które dają możliwość utrzymywania żądanej temperatury i wilgotności z dużą dokładnością. Podczas pracy komory (włącznie z prowadzeniem testów emisji i badaniami osiągów pojazdu), jest możliwa:

- kontrola temperatury powietrza w komorze w zakresie od $-35{ }^{\circ} \mathrm{C}$ do $+60{ }^{\circ} \mathrm{C}$

- dokładność ustawień (tolerancja temperatury): $\pm 1,0{ }^{\circ} \mathrm{C}$ (w warunkach statycznych, bez wydzielania ciepła); 

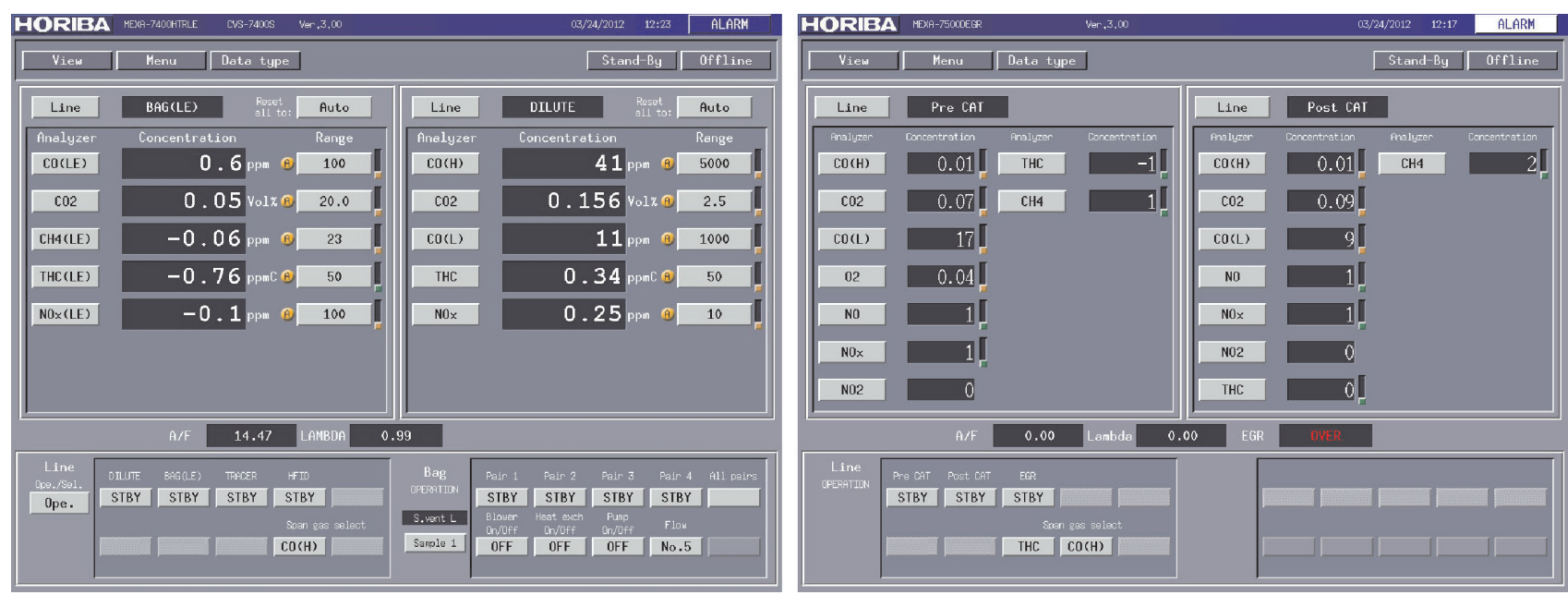

Fig. 5. Screenshots from the MEXA7000HRTLE (left) and MEXA7500DEGR (right) control systems, showing Bag LE, Diluted, PreCat and PostCat lines

Rys. 5. Ekrany komputerów sterujących praca analizatorów spalin MEXA7000HRTLE (po lewej) i MEXA7500DEGR (po prawej) przedstawiające następujące linie analizatorów: Bag LE, Diulted (pomiar spalin rozcieńczonych), PreCat (przed reaktorem katalitycznym) i PostCat (za reaktorem katalitycznym)

The VETS system automates the signal sent to the driver's aid, and includes options for testing over all the test cycles previously mentioned. Additionally, the software monitors chamber environmental parameters (temperature, pressure, humidity) as well as ambient concentrations of $\mathrm{HC}, \mathrm{CO}, \mathrm{NO}_{\mathrm{x}}$ etc. within the chamber to ensure that each test is safe, reliable, repeatable and thoroughly documented. This software also handles the indirect measurement of emissions which are calculated mathematically, rather than measured directly, shown in simplified form in equations $1 \& 2$ :

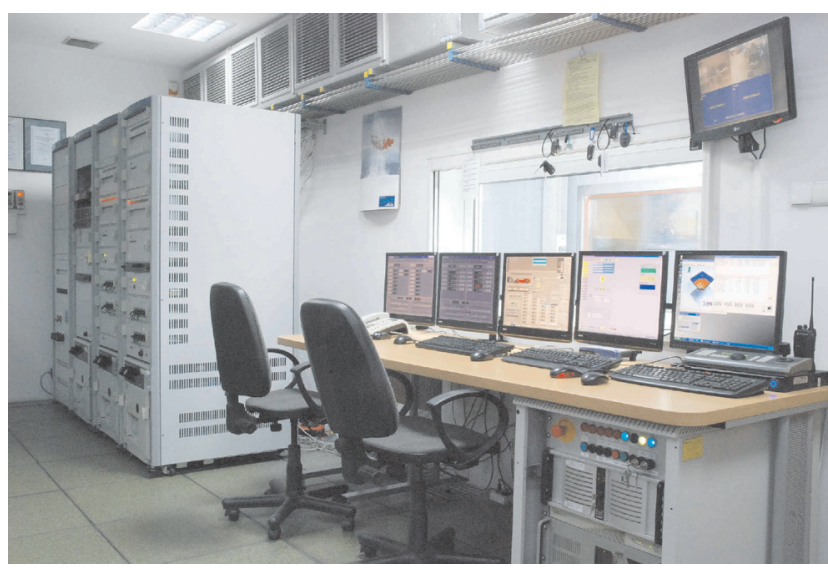

Fig. 6. View of the operator's workstation in the upgraded laboratory, showing the analyser racks (left), including the recently added MEXA7500DEGR bench; and the monitors of the computer control systems (left to right: raw emissions, bag and diluted emissions, VETS control system, chassis dynamometer control system, climatic chamber control system; above: chamber CCTV monitor)

Rys. 6. Pomieszczenie operatora w laboratorium emisji przedstawiajace zestawy analizatorów (po lewej), razem z nowym zestawem MEXA7500DEGR oraz monitory komputerowych systemów kontroli (od lewej do prawej: linia spalin surowych PreCat i PostCat, linie BagLE $i$ Diulted, system zarzadzania pomiarami VETS, system kontroli hamowni podwoziowej, system kontroli komory klimatycznej, powyżej-system monitorowania komory) $\pm 1,2{ }^{\circ} \mathrm{C}$ (w czasie testów emisyjnych); $\pm 2{ }^{\circ} \mathrm{C}$ (w czasie prób osiągów pojazdu)

- kontrola wilgotności powietrza podczas testów emisyjnych: od 5,5 do 15,0 g wody na kilogram suchego powietrza w zakresie temperatur od +20 do $+35^{\circ} \mathrm{C}$

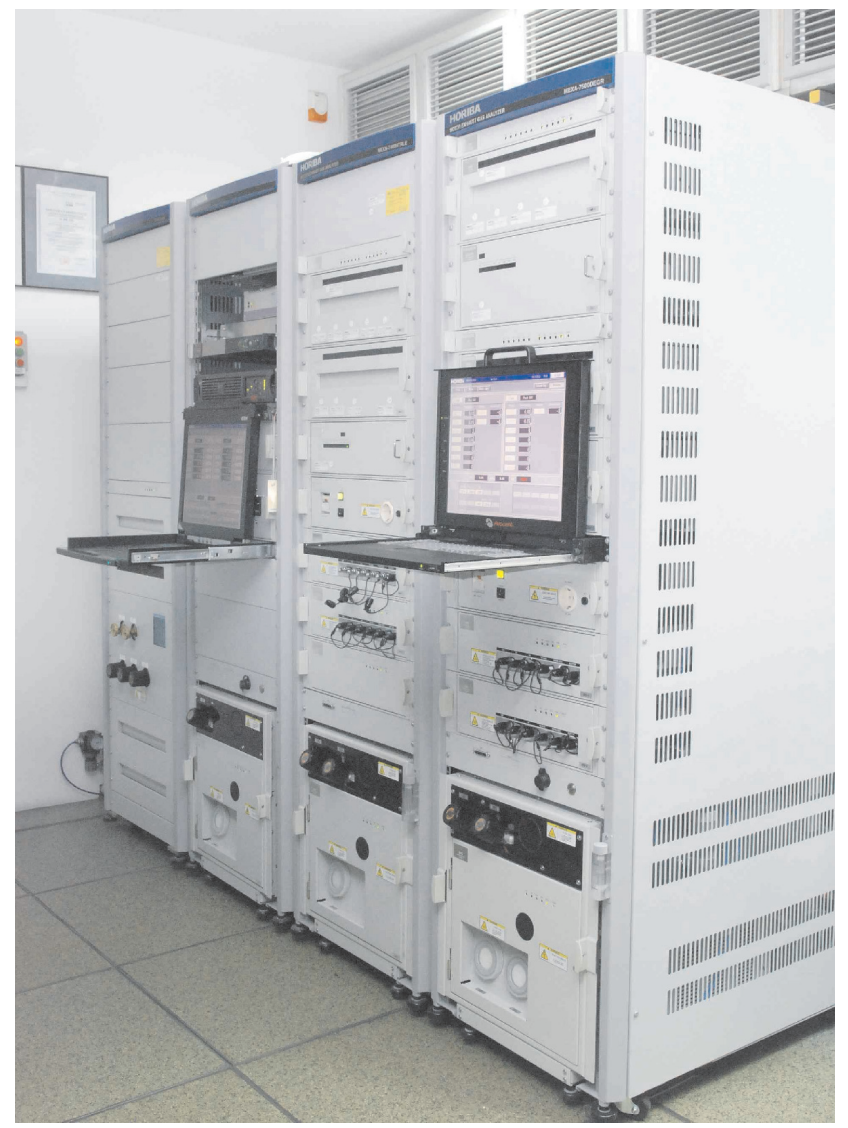

Fig. 7. MEXA-7400HTRLE (left) and MEXA-7500DEGR (right) Emissions Analysis systems

Rys. 7. Zestaw analizatorów MEXA-7400HTRLE (po lewej) i MEXA7500DEGR (po prawej) 


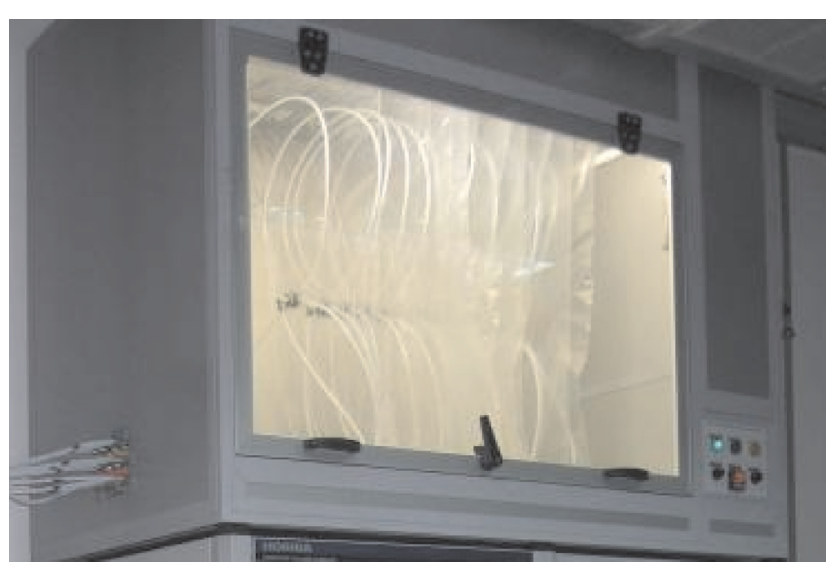

Fig. 8. Sample bags within their climate-controlled enclosure

Rys. 8. Worki na próbki spalin umieszczone w klimatyzowanej obudowie

$$
\begin{gathered}
\mathrm{THC}-\mathrm{CH}_{4}=\mathrm{NMHC} \\
\mathrm{NO}_{\mathrm{x}}-\mathrm{NO}=\mathrm{NO}_{2}
\end{gathered}
$$

\subsection{Facilities for accurate measurement of particulate} mass and number at low emission levels

Euro $5 \mathrm{~b}$ emissions legislation introduced a particulate number $(\mathrm{PN})$ limit in the range of particle diameters $23-$ $300 \mathrm{~nm}$ in addition to the particulate mass (PM) limit for vehicles with CI engines. Quantification of particle numbers in automotive exhaust is a more formal, rigorous metric than measuring exhaust gas opacity [2], and shows better repeatability than mass based measurements at very low emission levels, especially for CI engines equipped with a diesel particulate filter (DPF). The particle number count-
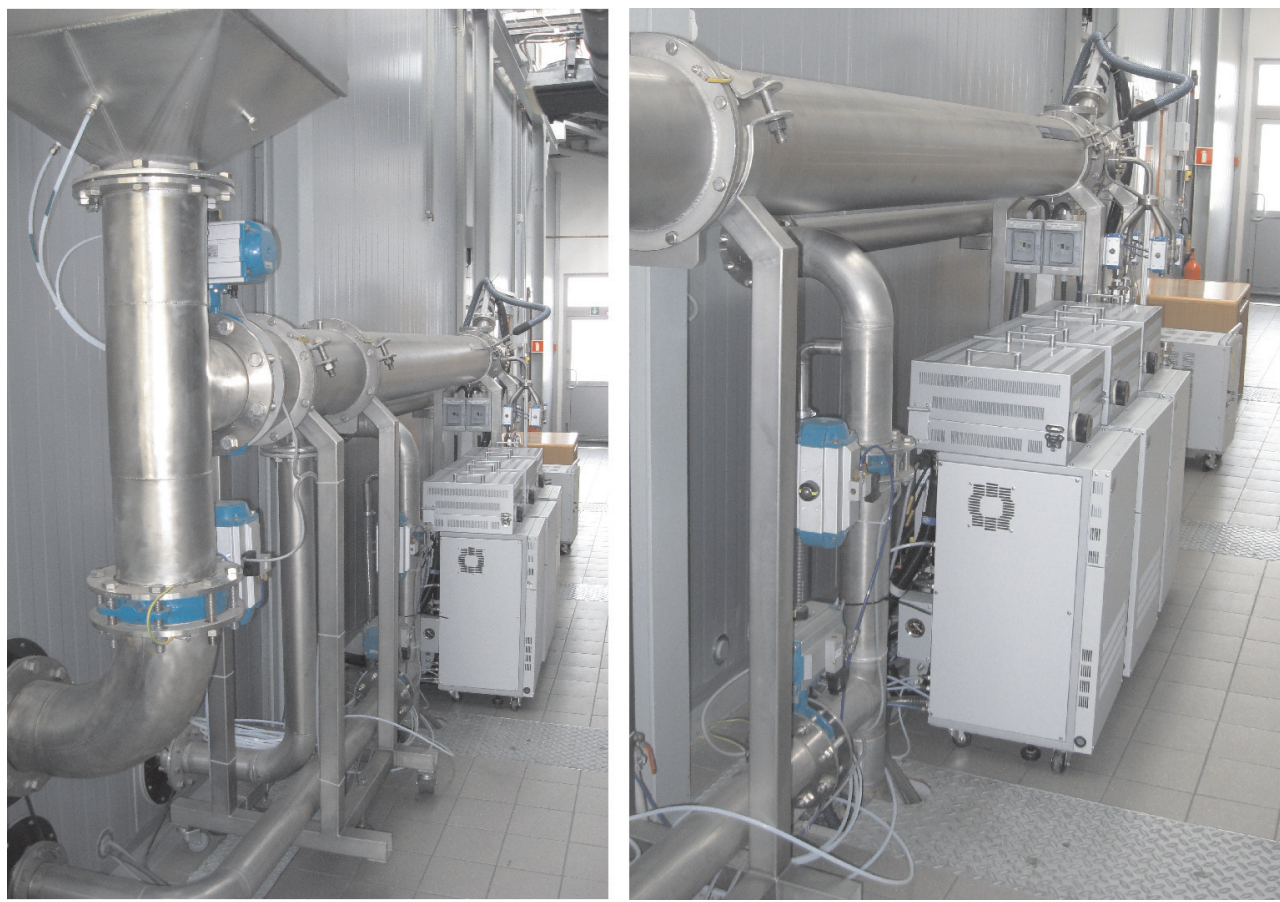

Fig. 9. Two views of the dilution tunnel (facing downstream), showing the heated OVN units for measuring emissions of THC, $\mathrm{CH}_{4}$ and $\mathrm{NO}_{\mathrm{x}}$ positioned under the tunnel

Rys. 9. Tunel rozcieńczajacy spaliny wraz z podgrzewanymi zestawami analizatorów do pomiaru emisji THC, $\mathrm{CH}_{4}$ i $\mathrm{NO}$ umieszczonymi pod tunelem
- zmienność wilgotności: $\leq 5 \%$

- gradient temperatury (w pustej kabinie): $0,5^{\circ} \mathrm{C}$ na minutę podczas faz nagrzewania i schładzania.

Oprogramowanie systemu komputerowego sterującego funkcjonowaniem komory klimatycznej pozwala na wykonanie zdefiniowanych przez użytkownika zautomatyzowanych działań, tak by stabilizacja temperatury mogła być osiągnięta przed rozpoczęciem jakiegokolwiek testu badawczego (rys. 4). Na wewnętrznej części dachu komory zamontowane sa standardowe lampy do zapewnienia równomiernego oświetlenia w kabinie, ale mogą one być zastąpione lampami solarnymi dużej mocy, tak jak jest to niezbędne podczas specjalnego testu emisji dla układów klimatyzacji samochodu, wymaganego przez EPA/CARB('SC03'), który jest wykonywany w temperaturze otocznia $35^{\circ} \mathrm{C}[5]$.

$\mathrm{W}$ podłodze laboratorium emisji zainstalowana jest hamownia podwoziowa (AVL Zoellner 48" compact), co w połączeniu z systemem zarządzania pomiarami HORIBA VETS NT pozwala na wykonanie wielu różnorodnych badawczych cykli jezdnych (NEDC, UDC, FTP-75, US06, SC03, HWFET i innych); nowe cykle jezdne mogą być szybko zaimplementowane przez możliwe zmiany w oprogramowaniu - wstępna wersja nowo planowanego cyklu WLTC została ostatnio dodana do zakresu wykonywanych testów. Hamownia podwoziowa i jej komputerowy system sterujący dokładnie opisano w publikacji autorów tej pracy [1].

\subsection{Rozbudowa systemu pomiarowego do badań emisji związków szkodliwych spalin}

Laboratorium badania emisji spalin wyposażone jest w rozbudowany zestaw do pomiarów emisji związków szkodliwych spalin. Składa się on z układu próbkowania spalin CVS-CFV wraz z tunelem rozcieńczającym spaliny powietrzem i systemem próbkowania cząstek stałych, urządzenia do pomiaru liczby cząstek stałych - PN, zestawu analizatorów spalin (rys. 6.) do pomiarów stężenia tlenku węgla, dwutlenku węgla, węglowodorów THC, metanu, węglowodorów niemetanowych NMHC, tlenków azotu (NO $+\mathrm{NO}_{2}$ ) (rys. 5, tab. 1). Nowym elementem systemu pomiarowego jest dodatkowy zestaw analizatorów służący do pomiaru stężenia $\mathrm{HC}, \mathrm{CH}_{4}, \mathrm{NMHC}$, $\mathrm{CO}, \mathrm{CO}_{2}, \mathrm{O}_{2}, \mathrm{NO}, \mathrm{NO}_{2}$, $\mathrm{NO}_{x}$ w nierozcieńczonych spalinach i stopnia recyrkulacji spalin EGR. Wszystkie pomiary i badania emisji związków szkodliwych spalin zarządzane są przez 
ing system installed in 2010 is described in [1] and shown in Fig. 11. In addition to testing activities on CI engines, as required by Euro 5b legislation, this device has also recently been used to measure the particle number emissions from SI engines operating on various fuel types [16, 17], and to investigate emissions from DI SI engines (in connection with - and anticipation of - the upcoming PN limits for this engine type) [18].

New Euro 5b and Euro 6 emission legislations also require increased accuracy of particulate samples filter weighing, as well as specially equipped climatic rooms in which to install the microbalance for filter weighing. The climatic chamber for stabilisation and weighing of PM membrane filters for use in emission tests has been described previously [1], and is shown in Fig. 12. The temperature inside the chamber is maintained within the range $20^{\circ} \mathrm{C}-30{ }^{\circ} \mathrm{C}$ (with a tolerance of $\pm 2{ }^{\circ} \mathrm{C}$ ), and the humidity is maintained within

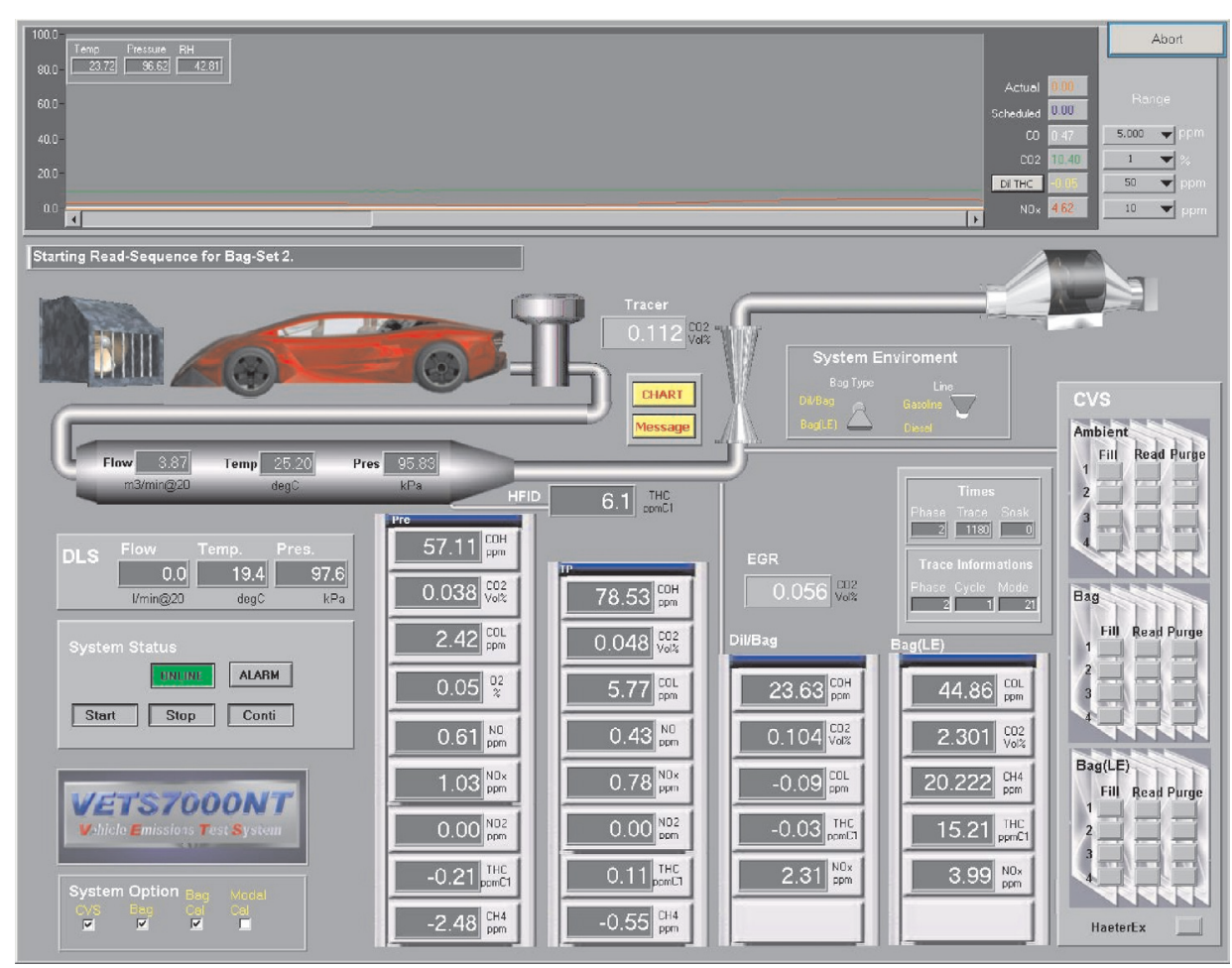

Fig. 10. Screenshot from VETS during emissions testing on a Diesel vehicle, showing online values for the Pre-cat, Post-cat and Diluted emissions analysis systems, as well as environmental parameters from the constant volume sampling system

Rys. 10. Ekran systemu VETS podczas testu emisji samochodu z silnikiem o zapłonie samoczynnym, przedstawiający rzeczywiste wartości stężeń mierzonych związków dla wszystkich punktów pomiarowych, jak również parametry mieszaniny spalin z powietrzem przepływajacej przez system poboru spalin komputerowy system sterowania pomiarami w laboratorium emisji VETS. Rysunki 6 i 7 przedstawiają widok ogólny układu sterowania i zarządzania pomiarami w laboratorium emisji. Worki pomiarowe, do których próbkuje się gazy spalinowe rozcieńczone powietrzem zamontowane są w specjalnej obudowie, w której temperatura utrzymywana jest na poziomie $35^{\circ} \mathrm{C}$ w celu zapobiegania kondensacji niektórych węglowodorów (rys. 8). Analizatory mierzące stężenie THC, $\mathrm{CH}_{4}$ i NO $\mathrm{NO}_{x}$ w gazach nierozcieńczonych umieszczone są w oddzielnych jednostkach przystosowanych do próbkowania gazów przez podgrzewane przewody (rys. 9).

W pierwszym etapie inwestycji w laboratorium zostały zainstalowane dwie niezależne linie do próbkowania spalin: osobna linia dla silników o zapłonie iskrowym o niskiej emisji (LE) oraz druga linia dla silników o zapłonie samoczynnym [1]. Obecna modernizacja układu pomiarowego emisji spalin objęła instalację dodatkowych linii pomiarowych do analizy nierozcieńczonych (surowych) spalin, składających się z analizatorów i linii grzanych o wystarczającej długości, umożliwiającej badania dowolnego pojazdu o masie do 3500 kg, zarówno z napędem na przednią, jak i tylną oś.

Jednym z kryteriów technicznych przy planowaniu budowy i wyposażenia laboratorium emisji była możliwość dodawania do niego nowych elementów wyposażenia celem sprostania rosnącym wymaganiom w zakresie wprowadzania nowych metodyk pomiarowych w badaniach emisji spalin. Wyposażenie laboratorium ostatnio uzupełniono o analizator $\mathrm{NH}_{3}$ dla umożliwienia badań emisji amoniaku w samochodach osobowych zarówno z silnikami o zapłonie samoczynnym, jak i z silnikami o zapłonie iskrowym, szczególnie zasilanymi CNG [14]. Prowadzono również pomiary z użyciem analiza-

the range $35 \%-55 \%$ (with a tolerance $\pm 6 \%$ ), throughout the prescribed stabilisation and weighing periods for the PM membrane filter.

The chamber features another recent addition to the range of equipment for the analysis of PM emissions - a Sartorius MSE2.7S ultramicrobalance, added February 2012 (Fig. 13). tora FTIR, umożliwiającego analizę emisji wielu regulowanych i nieregulowanych związków szkodliwych spalin [15]. W przyszłości w celu prowadzenia zaawansowanych prac badawczo-rozwojowych, w szczególności analizy paliw do silników ZS, silników ZI z wtryskiem bezpośrednim, a także badania filtrów cząstek stałych DPF zainstalowany obecnie licznik cząstek stałych może być uzupełniony o urządzenie do określania średnic i powierzchni tych cząstek. 
This advanced balance, designed and produced with the needs of the automotive testing process in mind, can measure objects of mass $0-2.1 \mathrm{~g}$. In the relevant range the balance has a rated accuracy of $0.0001 \mathrm{mg}$. The balance features an advanced levelling system, environmental stability monitoring and a sealable weighing crucible - all crucial tools for

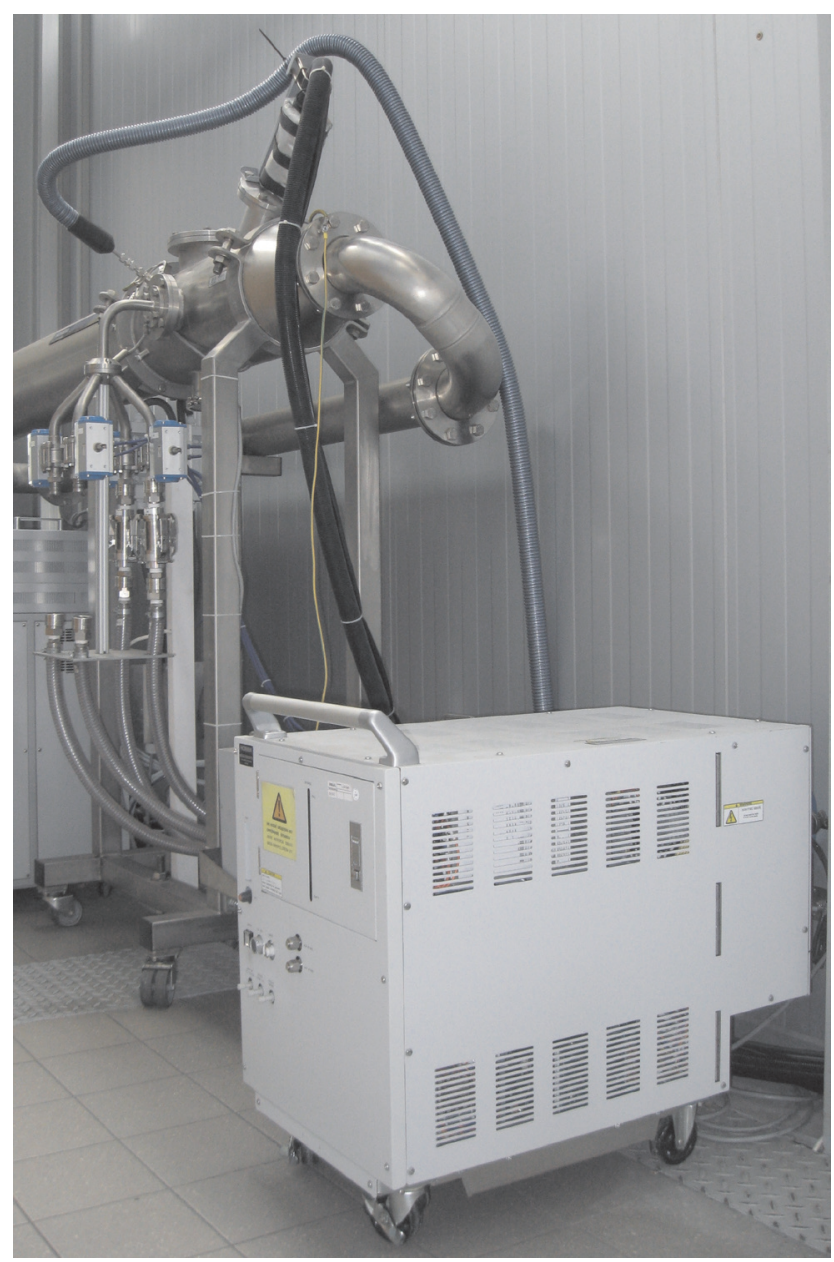

Fig. 11. Dilution tunnel (looking upstream), showing the filter cartridge installation (left), the heated particulate number counter sample transfer tube (blue), the heated HFID transfer tube (black), and the HORIBA 2000-SPCS PN counter (foreground)

Rys. 11. Tunel rozcieńczajacy, pokazujący sposób zainstalowania filtrów do pomiaru masy czastek statych, grzana linie poboru czastek (niebieska) do licznika cząstek statych, grzana linię poboru spalin (czarna) do analizatora HFID oraz licznik cząstek statych HORIBA 2000-SPCS

achieving accurate quantification of the $\delta_{\text {mass }}$ of the filter when testing vehicles featuring particle filters, where $\delta_{\text {mass }}$ over the entire driving cycle can be very small indeed - on the order of $0.5 \%$ of the mass of the filter itself.

\section{Summary}

On-going trends towards cleaner vehicles require accurate quantification of ever-decreasing concentrations of regulated pollutants. This trend, together with legal measures to reduce fuel consumption and general pressure to develop alternative powertrain concepts, are profoundly affecting the way in which vehicles are tested, as well as the facilities and equipment used in the testing process. $\mathrm{CO}_{2}$ emissions
Oprogramowanie sterujące pomiarami Horiba VETS7000NT zarządza działaniem analizatorów spalin i ich różnorodnymi funkcjami podczas testów emisji - m.in. takimi jak sprawdzanie zera i wartości maksymalnej stężenia gazu (rys. 10). System VETS przetwarza sygnał wysyłany do układu zadawania prędkości jazdy dla kierowcy (zmiany prędkości pojazdu w czasie, zmiany biegów) dla wszystkich cykli jezdnych wymienionych poprzednio. Dodatkowo system zarządzania monitoruje parametry otoczenia (temperaturę, ciśnienie, wilgotność), a także stężenia $\mathrm{HC}, \mathrm{CO}, \mathrm{NO}_{\mathrm{x}}$ i innych związków w powietrzu w otoczeniu (w komorze badawczej laboratorium), aby zapewnić odpowiednie bezpieczeństwo, wiarygodność i powtarzalność każdego testu badawczego. Daje także możliwość akwizycji wszystkich zebranych danych. Oprogramowanie służy również do obliczania emisji danego związku w sposób pośredni, przez obliczanie $\mathrm{z}$ zadanych formuł matematycznych, jeśli nie ma możliwości badania ich bezpośrednio. Uproszczone równania, to równania (1) i (2).

\subsection{Pomiary masy i liczby cząstek stałych}

Wymagania Euro 5b, dotyczące badania emisji związków szkodliwych z pojazdów samochodowych o masie całkowitej do $3500 \mathrm{~kg}$, wprowadziły obowiązek określania nie tylko masy emitowanych cząstek (PM), którą określa się metodą wagową przez pomiar masy cząstek osadzonych na filtrach zestawu próbkującego pobierającego spaliny z tunelu rozcieńczającego (rys. 11), ale także liczby cząstek stałych (PN) w przedziale ich średnic $27-300 \mathrm{~nm}$ dla samochodów z silnikami ZS. Pomiar liczby cząstek stałych w spalinach samochodów z silnikami spalinowymi ZS wyposażonymi w filtry cząstek stałych (DPF) jest o wiele bardziej dokładny niż pomiar masy emitowanych cząstek, ze względu na trudności z dokładnym określeniem masy cząstek samochodów niskoemisyjnych. Charakteryzuje go przy tym większa powtarzalność pomiarów przy niskich poziomach emisji cząstek stałych [2]. Urządzenie do zliczania cząstek stałych zainstalowano w laboratorium emisji w 2010 r. (rys. 11), a jego opis znajduje się w artykule autorów tej pracy [1]. Poza testami silników o zapłonie samoczynnym urządzenie to jest używane również do pomiaru ilości cząstek stałych w spalinach z silnika o zapłonie iskrowym z wtryskiem bezpośrednim paliwa, także przy zastosowaniu różnych rodzajów paliw $[16,17]$ (w związku z planowanym wprowadzeniem limitów PN dla silników ZI z wtryskiem bezpośrednim benzyny w wymaganiach Euro 6) [18].

Również nowe wymagania dotyczące badania emisji (Euro 5b i Euro 6) zmuszają do zwiększenia dokładności przy ważeniu filtrów z próbkami cząstek stałych i stawiają zaostrzone wymagania odnośnie do samej procedury ważenia filtrów. Klimatyzowane pomieszczenie wagowe do stabilizacji i ważenia membranowych filtrów cząstek stałych przedstawiono na rys. 12. Temperatura $\mathrm{w}$ pomieszczeniu może być utrzymywana w zakresie od $20{ }^{\circ} \mathrm{C}$ do $30{ }^{\circ} \mathrm{C}(\mathrm{z}$ tolerancją $\pm 2{ }^{\circ} \mathrm{C}$ ), a wilgotność pomiędzy $35 \%$ a $55 \%$ (z tolerancją $\pm 6 \%$ ) podczas stabilizacji i ważenia filtrów.

Pomieszczenie wagowe uzupełniono w bieżącym roku o nową ultramikro wagę typu Sartorius MSE2.7S (rys. 13). 
reduction is a challenge for the industry, driven by political, economic and technical factors. Ambitious mid- and longterm fleet average $\mathrm{CO}_{2}$ emissions targets represent multiple difficulties for vehicle manufacturers, requiring considerable $\mathrm{R} \& \mathrm{D}$ investment. Simultaneously, emissions regulation is becoming more stringent, with new pollutant compounds to analyse and test for: particle number (to become more important than PM mass), with $\mathrm{NO}_{2}, \mathrm{~N}_{2} \mathrm{O}, \mathrm{NH}_{3}, \mathrm{CH}_{4}$ and specific organic compounds as potential candidates for $\mathrm{EU}$ legislation [19-22].

Despite these two existential threats, IC engines appear highly likely to remain the most important power source for land transport, and development of these engines requires sophisticated test methods and very well-equipped laboratories, in order to meet these twin challenges. The design process must reflect the fact that an engine is no longer simply a collection of moving metallic components - fuels, lubricants and aftertreatment systems must be borne in mind during the engine design, development and testing processes. Further development of modern IC engine technology

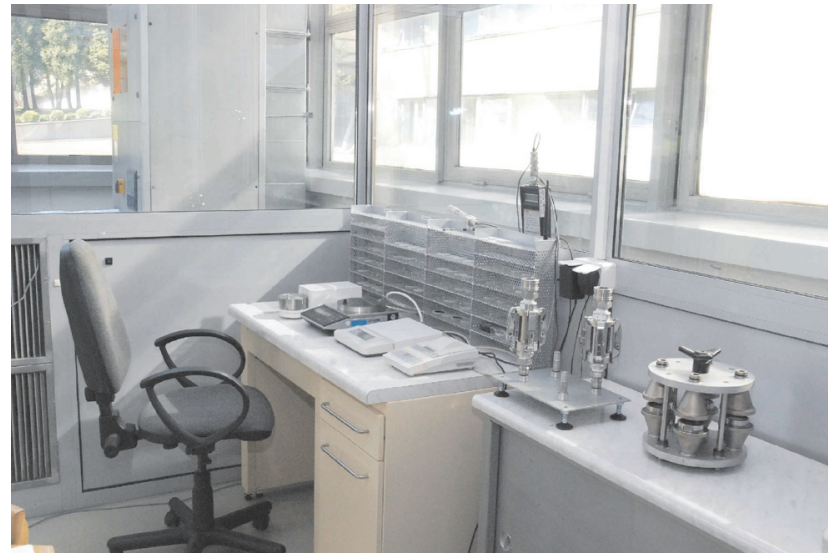

Fig. 12. The balance, filter conditioning racks and filter cartridges in the climate controlled weighing chamber

Rys. 12. Wagi i regal do sezonowania filtrów w klimatyzowanym pomieszczeniu wagowym

Jest to bardzo zaawansowana technicznie waga. Została zaprojektowana i wykonana na potrzeby spełnienia wymagań przy badaniu zanieczyszczeń emitowanych ze źródeł motoryzacyjnych. Umożliwia ona ważenie obiektów o masie od 0 do 2,1 g z dokładnością do $0,0001 \mathrm{mg}$. Waga wyposażona jest w zaawansowany system podnoszenia szalki, monitoring stabilności otoczenia, a także szczelną komorę pomiarową - wszystkie niezbędne elementy do uzyskiwania dokładnych pomiarów masy cząstek stałych na filtrze, której wartość podczas całego cyklu jezdnego może być naprawdę mała, np. około $0,5 \%$ masy całego filtra.

\section{Podsumowanie}

Zmniejszenie globalnej, antropogenicznej emisji $\mathrm{CO}_{2}$ jest wyzwaniem dla przemysłu motoryzacyjnego spowodowanym czynnikami politycznymi, ekonomicznymi i technicznymi. Osiągniecie średnio- i długoterminowych poziomów średniej emisji flotowej $\mathrm{CO}_{2}$ jest bardzo skomplikowanym i kosztownym procesem dla producentów pojazdów, wymagającym zwiększonego inwestowania w prace badawczo-rozwojowe. Jednocześnie przepisy dotyczące emisji szkodliwych składników spalin stają się coraz bardziej restrykcyjne, wliczając nowe związki chemiczne, które będzie należało poddać analizie: liczba cząstek stałych (obecnie ważniejsza niż masa cząstek), tlenki azotu, takie jak: $\mathrm{NO}, \mathrm{NO}_{2}, \mathrm{~N}_{2} \mathrm{O}$, amoniak $-\mathrm{NH}_{3}$,

require enforced development tests in topical issues at the very heart of automotive development, including regulated and unregulated emissions $[14,15]$; alternative and gaseous fuels [15 - 19]; cold start $[7,20]$ to undertake quantitative research in areas which are key to the development of the automotive industry, the engine oil and fuel industries, their suppliers, and other allied areas. Catalytic aftertreatment systems remain very important for the reduction of emissions, provided that they remain practical and cost-effective.
$\mathrm{CH}_{4}$, specyficzne związki organiczne, które potencjalnie mogą znaleźć się w nowych przepisach (Euro 7, Tier 3, LEV III) dotyczących ograniczania emisji w krajach EU i USA [18, $21-24]$.

Pomimo wyzwań dotyczących konieczności dalszego ograniczania emisji związków szkodliwych i emisji $\mathrm{CO}_{2}$, silniki spalinowe prawdopodobnie przez jeszcze wiele dziesięcioleci pozostaną najważniejszym źródłem napędu stosowanym w transporcie drogowym, a ich rozwój będzie 
Similarly, biofuels and advanced lubricants will also be vital tools in our campaign to reduce harmful emissions, GHG emissions, and increase the security and sustainability of the transportation energy supply. All of these "weapons" in the fight to reduce harmful emissions and GHG emissions come with their own unique testing requirements.

The introduction of new, ever more stringent emissions standards, such as Euro 6, Euro 7, globally-harmonised limits (the WLTP) and local limits (city/local authority vehicle restrictions) $[18,21,22]$ necessitate continuous financial and intellectual investment in emissions testing systems, technical know-how and thorough knowledge of test procedures [21 - 24]. In addition to changes to testing hardware and its control software, test methods must be continually evaluated and developed, in concert with the demands of relevant legislation and private customers' expectations and test specifications [21 - 24]. The rapid integration of these latest additions to the laboratory testifies to its fulfilment of the laboratory's design criterion that it be modular and upgradeable. Based on the success of the recent installations, in future further modules and upgrades could be added, to enable quantification of as yet unregulated compounds, based on the new emissions requirements and worldwide automotive market expectation.

\section{Abbreviations/Skróty i oznaczenia}

CARB California Air Resources Board/Kalifornijska Rada Ochrony Powietrza

CI Compression ignition/silniki z zapłonem samoczynnym $Z S$

CNG Compressed natural gas/sprężony gaz ziemny

CVS Constant volume sampling/pobieranie próbek stałej objętości

DI Direct injection/wtrysk bezpośredni

DPF Diesel particulate filter/filtr czastek statych

EPA Environmental Protection Agency/Agencja Ochrony Środowiska USA

EU European Union/Unia Europejska

GHG Greenhouse gas emissions/emisja gazów cieplarnianych $\mathrm{nm}$ nanometer/nanometr

PM Particulate mass/masa czastek statych

PN Particle number/liczba czastek statych

PNC Particle number counter/licznik cząstek statych

ppm Parts per million/części na milion

SI Spark ignition/silniki o zapłonie iskrowym - ZI

SI DI Spark ignition direct injection/silniki benzynowe o wtrysku bezpośrednim

VETS Vehicle emissions testing system/system badania emisji pojazdów

WLTP Worldwide harmonized light-duty test procedures/nowa procedura badania emisji z lekkich pojazdów samochodowych wymagał stosowania skomplikowanych metod badawczych i bardzo dobrze wyposażonych laboratoriów, by sprostać tym wymaganiom. Proces projektowania silnika powinien odzwierciedlać fakt, iż silnik spalinowy nie jest już tylko zestawem poruszających się części mechanicznych - układy zasilania paliwem i powietrzem, układy smarowania i oleje smarne. Także systemy oczyszczania spalin są integralną częścią silnika i muszą być projektowane wspólnie oraz razem poddawane badaniom. Dalszy rozwój konstrukcji silników spalinowych wymaga intensywnych prac badawczych nad takimi problemami, jak emisja po rozruchu zimnego silnika $[7,20]$, obniżanie poziomu emisji innych składników spalin, obecnie nielimitowanych $[14,15]$, wzrost zainteresowania paliwami alternatywnymi i gazowymi i badania ich wpływu na poziom emisji związków szkodliwych w spalinach [15 - 19]. Nowe technologie dotyczące konstrukcji reaktorów katalitycznych i nowych stopów metali szlachetnych, które są obecnie rozwijane, zapewnią systemom katalitycznego oczyszczania spalin znaczące miejsce w zmniejszaniu całkowitej emisji spalin z silnika. Podobnie wzrost znaczenia biopaliw i zaawansowane technologicznie oleje smarne będą również znacząco wpływały na obniżenie uciążliwej emisji spalin, emisji gazów cieplarnianych (GHG) i zwiększenie bezpieczeństwa energetycznego oraz bardziej oszczędnego użytkowania zasobów paliw przez sektor transportu.

Wprowadzanie nowych, coraz surowszych norm ograniczania emisji samochodowej jak Euro 6, Euro 7, standardów globalnych (WLTP) i lokalnych (restrykcje w miastach dotyczące wjazdu i ruchu pojazdów) [18, 21, 22], wymagają nieustannych inwestycji związanych z wyposażeniem laboratoriów do badań emisji, zdobywaniem wiedzy technicznej na temat nowych metod analizy spalin, a także znajomości procedur umożliwiających ich badanie [21 - 24]. W celu sprostania wymaganiom prawnym metody badawcze muszą być stale oceniane i rozwijane w związku ze stałymi zmianami zarówno aparatury pomiarowej, jak i stosowanych programów komputerowych. Możliwość szybkiej integracji nowych układów pomiarowych zamontowanych w laboratorium badania emisji związków szkodliwych spalin samochodowych dowodzi spełnienia kryterium projektowego dotyczącego modularnej budowy laboratorium i możliwości jego dalszego rozwoju, co jest niezbędne w rywalizacji na międzynarodowym rynku motoryzacyjnym w badaniach i rozwoju nowoczesnych konstrukcji silników spalinowych i pojazdów samochodowych, bardziej przyjaznych środowisku naturalnemu i oszczędniejszych pod kątem zużycia paliwa.

\section{Bibliography/Literatura}

[1] Bielaczyc P., Szczotka A., Pajdowski P., Woodburn J.: Development of vehicle exhaust emission testing methods - BOSMAL's new emission testing laboratory. Combustion Engines/ Silniki Spalinowe, 1/2011 (144), 3-12, 2011.
[2] Bielaczyc P.: Exhaust pollutants and $\mathrm{CO} 2$ emissions reduction as the main drivers of automobile powertrain development. Proceedings of The First International Exhaust Emissions Symposium, Bielsko-Biala, Poland, May 2010. 
[3] Bielaczyc P., Woodburn J.: Global trends in emissions regulation and reduction. Combustion Engines/ Silniki Spalinowe, Paper 2010-SS3-301, 3/2010 (142), 3-27, 2010.

[4] Commission Regulation (EC) No 692/2008 of 18 July 2008 implementing and amending Regulation (EC) No 715/2007 of the European Parliament and of the Council on type-approval of motor vehicles with respect to emissions from light passenger and commercial vehicles (Euro 5 and Euro 6) and on access to vehicle repair and maintenance information. Official Journal of the European Union, L199, 1-136, 28.7.2008.

[5] California Air Resources Board Exhaust Emission Standards and Test Procedures for 2001 and Subsequent Model Passenger Cars, Light-Duty Trucks, and Medium-Duty Vehicles. Last amended: 02.12.2009. Available online: http://www.arb.ca.gov

[6] United States Code of Federal Regulations, Title 40, Chapter I, Parts 81-99, revised as of 1 July 2010. Available online: http:// ecfr.gpoaccess.gov

[7] Bielaczyc P., Szczotka A., Woodburn J.: The effect of a low ambient temperature on the cold-start emissions and fuel consumption of passenger cars. Proceedings of the Institution of Mechanical Engineers, Part D: Journal of Automobile Engineering, 225, 9 2011. DOI: 10.1177/0954407011406613.

[8] Weilenmann M. et al.: Regulated and nonregulated diesel and gasoline cold start emissions at different temperatures. Atmos. Environ., 2005, 39, 2433-2441.

[9] Weilenmann M., Favez,J.-Y., Alvarez R.: Cold-start emissions of modern passenger cars at different low ambient temperatures and their evolution over vehicle legislation categories. Atmos. Environ., 2009, 43, 2419-2429.

[10] Andrianov D., Manzie C., Brear M.: A Methodology for Minimising Emissions Constrained Cold Start Fuel Consumption, SAE Technical Paper 2012-01-0894, 2012, DOI: 10.4271/2012-01-0894.

[11] United Nations Economic Commission for Europe, Regulation no. 101 , series 05 .

[12] Council Directive 80/1268/EEC of 16 December 1980 on the approximation of the laws of the Member States relating to the fuel consumption of motor vehicles. Official Journal L 375, 36-45.

[13] United Nations Economic Commission for Europe Regulation no. 83 Series 05 Rev.1/Add.82/Rev.3/Amend.4.

[14] Bielaczyc P., Szczotka A., Swiatek,A., Woodburn J.: A comparison of ammonia emission factors from light-duty vehicles operating on gasoline, liquefied petroleum gas (LPG) and compressed natural gas (CNG), SAE Int. J. Fuels Lubr. 5(2):2012, DOI:10.4271/2012-01-1095.

Piotr Bielaczyc, DEng. - head of the Engine Research Department, BOSMAL Automotive Research and Development Institute Ltd in Bielsko-Biała.

Dr inż. Piotr Bielaczyc - kierownik Zakładu Badań Silników, Instytut Badań i Rozwoju Motoryzacji BOSMAL Sp. z o.o., Bielsko-Biała.

e-mail: piotr.bielaczyc@bosmal.com.pl

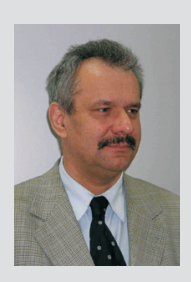

Piotr Pajdowski, DEng. - doctor in the Engine Research Department, BOSMAL Automotive Research and Development Institute Ltd in Bielsko-Biała.

Drinż. Piotr Pajdowski - adiunkt w Zaktadzie Badań Silników, Instytut Badań i Rozwoju Motoryzacji BOSMAL Sp. z o.o., Bielsko-Biała.

e-mail: piotr.pajdowski@bosmal.com.pl
[15] Bielaczyc P., Klimkiewicz D., Pajdowski P., Szczotka A., Woodburn J.: An examination of the effect of ethanol-gasoline blends' physicochemical properties on emissions from a light-duty spark ignition engine. : Fuel Processing Technology FUPROC3532, DOI: 10.1016/j.fuproc.2012.07.030.

[16] Bielaczyc P., Szczotka A., Woodburn J.: A study of gasolineethanol blends influence on performance and exhaust emissions from a light-duty gasoline engine, SAE Technical Paper 2012-01-1052, 2012, DOI:10.4271/2012-01-1052.

[17] Bielaczyc P., Szczotka,A., Woodburn J.: The effect of various petrol-ethanol blends on exhaust emissions and fuel consumption of an unmodified light-duty SI vehicle, SAE Technical Paper 2011-24-0177, 2011, DOI: 10.4271/2011-24-0177.

[18] Bielaczyc P., Woodburn J.: Analysis of current and future trends in automotive emissions, fuels, lubricants and test methods. Combustion Engines / Silniki Spalinowe, Paper PTNSS-2011-SS4-412, 4/2011 (147).

[19] Bielaczyc P., Klimkiewicz D., Szczotka A.: The potential of european light duty cng-fuelled vehicles to meet Euro 6 requirements, Combustion Engines / Silniki Spalinowe, Paper PTNSS-2012-SS4-403, No 4/2012 (151), 20-33.

[20] Bielaczyc P., Szczotka A., Woodburn J.: Excess emissions and fuel consumption of modern spark ignition passenger cars at low ambient temperatures, SAE Technical Paper 2012-011070, 2012, DOI: 10.4271/2012-01-1070.

[21] Hill L.: Future trends in emissions certification legislation and some implications for measurement techniques. Proceedings of The First International Exhaust Emissions Symposium, BielskoBiala, Poland, 20 May 2010. ISBN: 978-83-931383-0-2.

[22] Hill L.: Implications of Future Emissions Legislation on Emissions and Fuel Economy Testing Procedures and Equipment. Symposium Proceedings of the 2nd International Exhaust Emissions Symposium, Bielsko-Biala, Poland 26/27 May 2011. ISBN 978-83-931383-1-9, Combustion Engines/Silniki Spalinowe 4/2011 (147).

[23] Engeljehringer K.: Emission testing of modern vehicle concepts. Proceedings of The First International Exhaust Emissions Symposium, Bielsko-Biala, Poland, 20 May 2010. ISBN: 978-83-931383-0-2.

[24] Engeljehringer K.: Automotive Emission Testing and Certification - Past, Present and Future. Symposium Proceedings of the 2nd International Exhaust Emissions Symposium, BielskoBiala, Poland 26/27 May 2011. ISBN 978-83-931383-1-9, Combustion Engines/Silniki Spalinowe 4/2011 (147).

Andrzej Szczotka, DEng. - doctor in Engine Research Department at the BOSMAL Automotive Research \& Development Institute Ltd in Bielsko-Biała.

Dr inż. Andrzej Szczotka - adiunkt w Zaktadzie Badań Silników Instytut Badań i Rozwoju Motoryzacji BOSMAL Sp. z o.o., Bielsko-Biała.

e-mail: andrzej.szczotka@bosmal.com.pl

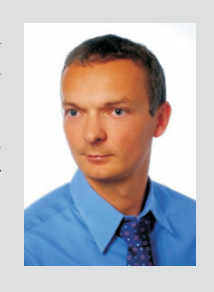

Joseph Woodburn, MSc. - researcher at the Engine Research Department, BOSMAL Automotive Research and Development Institute Ltd in Bielsko-Biała.

Mgr inż. Joseph Woodburn - inżynier ds. badań w Zakładzie Badań Silników, Instytut Badań i Rozwoju Motoryzacji BOSMAL Sp. z o.o., Bielsko-Biała. 